\title{
Article \\ Synthesis and Characterization of PdAgNi/C Trimetallic Nanoparticles for Ethanol Electrooxidation
}

\author{
Ahmed Elsheikh 1,2,*(D) and James McGregor $2, *$ (D) \\ 1 Mechanical Engineering Department, South Valley University, Qena 83511, Egypt \\ 2 Department of Chemical and Biological Engineering, University of Sheffield, Sheffield S1 3JD, UK \\ * Correspondence: ahmed.elsheikh@eng.svu.edu.eg (A.E.); james.mcgregor@sheffield.ac.uk (J.M.)
}

Citation: Elsheikh, A.; McGregor, J. Synthesis and Characterization of PdAgNi/C Trimetallic Nanoparticles for Ethanol Electrooxidation. Nanomaterials 2021, 11, 2244. https:// doi.org/10.3390/nano11092244

Academic Editor: Eva Pellicer

Received: 28 July 2021

Accepted: 27 August 2021

Published: 30 August 2021

Publisher's Note: MDPI stays neutral with regard to jurisdictional claims in published maps and institutional affiliations.

Copyright: (c) 2021 by the authors. Licensee MDPI, Basel, Switzerland. This article is an open access article distributed under the terms and conditions of the Creative Commons Attribution (CC BY) license (https:// creativecommons.org/licenses/by/ $4.0 /)$.

\begin{abstract}
The direct use of ethanol in fuel cells presents unprecedented economic, technical, and environmental opportunities in energy conversion. However, complex challenges need to be resolved. For instance, ethanol oxidation reaction (EOR) requires breaking the rigid $\mathrm{C}-\mathrm{C}$ bond and results in the generation of poisoning carbonaceous species. Therefore, new designs of the catalyst electrode are necessary. In this work, two trimetallic $\mathrm{Pd}_{\mathrm{x}} \mathrm{Ag}_{\mathrm{y}} \mathrm{Ni}_{\mathrm{z}} / \mathrm{C}$ samples are prepared using a facile borohydride reduction route. The catalysts are characterized by X-ray diffraction (XRD), Energy-Dispersive X-ray spectroscopy (EDX), X-ray photoelectron Spectroscopy (XPS), and Transmission Electron Microscopy (TEM) and evaluated for EOR through cyclic voltammetry (CV), chronoamperometry (CA), and electrochemical impedance spectroscopy (EIS). The XRD patterns have shown a weak alloying potential between $\mathrm{Pd}$, and Ag prepared through co-reduction technique. The catalysts prepared have generally shown enhanced performance compared to previously reported ones, suggesting that the applied synthesis may be suitable for catalyst mass production. Moreover, the addition of $\mathrm{Ag}$ and $\mathrm{Ni}$ has improved the Pd physiochemical properties and electrocatalytic performance towards EOR in addition to reducing cell fabrication costs. In addition to containing less Pd, The $\mathrm{PdAgNi} / \mathrm{C}$ is the higher performing of the two trimetallic samples presenting a $2.7 \mathrm{~A} / \mathrm{mg}_{\mathrm{Pd}}$ oxidation current peak. The $\mathrm{Pd}_{4} \mathrm{Ag}_{2} \mathrm{Ni}_{1} / \mathrm{C}$ is higher performing in terms of its steady-state current density and electrochemical active surface area.
\end{abstract}

Keywords: intermetallic XRD patterns; alloy formation; ethanol electrooxidation; metal segregation; borohydride reduction; fuel cells

\section{Introduction}

Fuel cells are electrochemical energy conversion devices capable of converting the fuel chemical energy into electricity [1,2]. They possess multiple technical and environmental advantages considering the decaying fossil fuel resources and growing energy needs. Their operation is theoretically $100 \%$ efficient because they are not restricted by the Carnot thermal/mechanical energy conversion limitation of conventional heat engines [3]. Direct ethanol fuel cells (DEFCs) are fed with liquid ethanol instead of hydrogen. DEFCs are friendly to the environment and present high flexibility to supply diverse energy needs. As a liquid, ethanol is easy to store and transport and presents a high energy density $(8 \mathrm{kWh} / \mathrm{kg}$ ) [4-7]. Furthermore, it can be produced from biomass resources such as sugar cane, corn, and, more recently, from diverse agricultural and biomass wastes and residues which means it is sustainable and carbon-neutral [5]. Despite these advantages, the full commercialization of DEFCs is far from being realized. There are difficult-to-overcome challenges mainly in the form of cell fabrication costs. All low-temperature fuel cells need active noble metal $(\mathrm{Pt})$ catalysts to push the fuel oxidation and oxidant reduction reactions forward. Another challenge is that most $\mathrm{C}$-containing fuels generate $\mathrm{CO}$-species during their oxidation. These poison catalytic sites and prevent further reaction, even if present only in low concentrations, e.g., 50 ppm [8,9]. Additionally, ethanol contains a strong C-C 
bond thereby favoring its incomplete oxidation to acetate instead of $\mathrm{CO}_{2}$ and releasing only 4 electrons instead of 12 [10,11]. Pt is very active for fuel cell electrocatalysis but is very expensive and scarce at the same time. Its expense can account for half of the cell fabrication [12]. There is, therefore, a need to find a Pt-alternative that presents comparable activity but also is more abundant to decrease the cell fabrication cost. Pd is more abundant than Pt and has shown a comparable performance for fuel cell electrocatalysis in alkaline electrolyte [13-15]. The fluctuating $\mathrm{Pd}$ and $\mathrm{Pt}$ prices are a complex phenomenon that involves technological, economic, and political contributions [16,17]. South Africa, Russia, Zimbabwe, Canada, and USA have Pd and Pt deposits. Prior to 1990, Pd was generally cheaper than $\mathrm{Pt}$ to mine and produce. However, with the advancement of Pd-based autocatalytic systems by the mid-90s, the demand and cost of Pd soared. By 2000, the price of $\mathrm{Pd}$ was much higher than that of $\mathrm{Pt}$ [18]. However, in 2007, the prices of $\mathrm{Pt}$ and $\mathrm{Pd}$ were reported $\$ 1450$ /ounce and $\$ 450$ /ounce, respectively [19]. Still, however, Pd is more attractive for automakers because it is not easy to switch back to Pt-catalytic converters. Furthermore, the diversity of Pd production by country and region is higher than that of Pt. South Africa, solely, controls Pt production while Pd mining capabilities are shared by Russia, South Africa, and North America [18]. This is an important factor due to the potential of a future shortage of Pt which is less likely in the case of Pd [20]. Another advantage of $\mathrm{Pd}$ over $\mathrm{Pt}$ in this particular EOR application is that it is more $\mathrm{CO}$ tolerant than $\mathrm{Pt}$, however, $\mathrm{Pt}$ is more $\mathrm{CO}_{2}$ selective than $\mathrm{Pd}$ [21]. To achieve a high-surface-area, $\mathrm{Pd}$ nanoparticles are dispersed on an inert, conducting, and porous material such as carbon black.

To further enhance the performance pf Pd and to decrease cell fabrication expenses, it is recommended to add another metal (or two) during the synthesis. The cocatalyst metal is expected to activate water and generate $\mathrm{OH}$ species to facilitate the oxidation of adsorbed ethoxy species. Moreover, it would modify the Pd geometry and electronic configuration and tune in its adsorption characteristics. Ni has been proven a beneficial cocatalyst when added to $\mathrm{Pd}$ because it can generate $\mathrm{OH}$ at a lower applied potential and modify the electronic structure of $\mathrm{Pd}$ [22-27]. The coexistence of $\mathrm{Ni}$ and $\mathrm{Ni}(\mathrm{OH})_{2}$ can enhance alcohol oxidation on transition metals in acidic and basic electrolytes [6,28]. Feng et al. [29] prepared unsupported porous $\mathrm{Pd}$ and PdNi catalysts for ethanol electrooxidation sowing that PdNi exhibits enhanced electrocatalytic performance when compared to monometallic Pd. This enhancement is ascribed to the electronic and bifunctional effects of Ni. Zhang et al. [27] prepared various-proportion $\mathrm{Pd}_{x} \mathrm{Ni}_{y} / \mathrm{C}$ catalysts for ethanol oxidation reaction. They found that $\mathrm{Ni}$ can generate oxygen species at lower applied potential, recovering $\mathrm{Pd}$ active sites and thus promoting ethanol oxidation, while through the microemulsion syntheis method it was possible to control PdNi particle size and make efficient contact between $\mathrm{Pd}$ and Ni. You et al. [30] prepared bimetallic PdAg dendrites with various composition and porous structure and evaluated them towards ethanol oxidation. Alloying between $\mathrm{Pd}$ and $\mathrm{Ag}$ shifts up the Pd d-band center leading to more tolerance for intermediates and poisons during EOR. Elsewhere, Li et al. [31] prepared PdAg nanoparticles supported on reduced graphene oxide (RGO), noting enhanced ethanol and methanol oxidation on PdAg when compared to Pd only. Oliveira et al. [32] prepared PdAg alloys and tested their efficacy for oxygen reduction reaction (ORR) and EOR. The kinetics of both reactions are promoted on $\mathrm{PdAg}$ as compared to Pd only. Additionally, the alloys maintained a higher selectivity for ORR in presence of ethanol. Similar conclusions on the benefits of adding Ag to Pd have been reported elsewhere [33,34].

In this work, trimetallic samples of $\mathrm{C}$-supported $\mathrm{PdAgNi}$ nanoparticles are prepared, characterized, and evaluated for ethanol oxidation reaction (EOR) for the first time. Pd-based bimetallic nanocatalysts have been extensively investigated and reported for fuel cell electrocatalysis and EOR. Yet, a few groups have pursued the synthesis and application of C-supported trimetallic samples for similar purposes [35-43]. It is postulated that adding two metals is likely to provide benefits towards ethanol oxidation through altering Pd geometry, surface configuration, adsorption capacity, and coordination [35,37-39,44,45]. 
However, several factors such as the metal chemistry, synthesis method, reducing agent, and support structure may adversely affect the outcome. The ultimate objective is to design new electrodes that are cost-effective, EOR-active, $\mathrm{CO}$-tolerant, and $\mathrm{CO}_{2}$-selective.

\section{Materials and Methods}

The applied borohydride reduction synthesis method follows [46-48]. Table 1 shows the added precursor quantities of Vulcan carbon (XC72R), $\mathrm{PdCl}_{2}, \mathrm{NiCl}_{2}$, and $\mathrm{AgNO}_{3}$ to prepare the monometallic and trimetallic samples. The theoretical metal loading was fixed at $12 \mathrm{Wt}$. \%. The metal and carbon precursors were sonicated in a mixture of 2-propanol and water $(50 / 50 \mathrm{v} / \mathrm{v})$ for a few minutes. The theoretical Pd:Ag:Ni molar ratio is 57:28:15 and 34:33:33 for $\mathrm{Pd}_{4} \mathrm{Ag}_{2} \mathrm{Ni}_{1} / \mathrm{C}$ and $\mathrm{PdAgNi} / \mathrm{C}$, respectively. The metallic salts were purchased from Sigma-Aldrich (Gillingham, United Kingdom) and the vulcan carbon precursor from Cabot Corp (Boston, MA, USA).

Table 1. Stochiometric added quantities of $\mathrm{C}, \mathrm{PdCl}_{2}, \mathrm{AgNO}_{3}, \mathrm{NiCl}_{2}$ to synthesize $\mathrm{Pd} / \mathrm{C}$. $\mathrm{PdAgNi} / \mathrm{C}$, and $\mathrm{Pd}_{4} \mathrm{Ag}_{2} \mathrm{Ni}_{1} / \mathrm{C}$.

\begin{tabular}{cccccc}
\hline Catalyst & $\mathbf{C}(\mathbf{m g})$ & $\left.\mathbf{P d C l}_{\mathbf{2}} \mathbf{( m g}\right)$ & $\mathbf{N i C l}_{\mathbf{2}} \mathbf{( m g )}$ & $\left.\mathbf{A g N O}_{\mathbf{3}} \mathbf{( m g}\right)$ & $\mathbf{M e t a l} \mathbf{W t .} \mathbf{\%}$ \\
\hline $\mathrm{Pd} / \mathrm{C}$ & 132 & 30 & & & 12 \\
$\mathrm{PdAgNi} / \mathrm{C}$ & 132 & 11.7 & 8.5 & 11.2 & 12 \\
$\mathrm{Pd}_{4} \mathrm{Ag}_{2} \mathrm{Ni}_{1} / \mathrm{C}$ & 132 & 18.3 & 3.4 & 8.8 & 12 \\
$\mathrm{Ag} / \mathrm{C}$ & 132 & & 40 & & 12 \\
$\mathrm{Ni} / \mathrm{C}$ & 132 & & & 28.3 & 12 \\
\hline
\end{tabular}

$\mathrm{KBr}$ was added as a capping agent following the anion exchange method; the larger $\mathrm{Br}^{-}$ion is capable of replacing the smaller $\mathrm{Cl}^{-}$ion in the vicinity of $\mathrm{Pd}[49,50]$. Consequently, $\mathrm{Br}^{-}$ions can surround the recently reduced metal hindering its coalescence. The $\mathrm{KBr} /$ Metal atomic ratio was adjusted to 1.5. After that, the mixture was stirred for $10 \mathrm{~min}$ followed by adding the $\mathrm{NaBH}_{4}$ solution $(0.5 \mathrm{M}, 15 \mathrm{~mL})$ in one portion. Subsequently, the whole mixture was vigorously stirred for $30 \mathrm{~min}$. Finally, the wet powder was dried at $80^{\circ} \mathrm{C}$ in vacuum oven overnight.

$\mathrm{X}$-ray diffraction (XRD) was undertaken to analyze the catalyst structure. The equipment is a Bruker D2 Phaser (Billerica, MA, USA) using $\mathrm{Cu} \mathrm{K} \alpha$ radiation at $30 \mathrm{kV}, 10 \mathrm{~mA}$, and $12^{\circ} / \mathrm{min}$ scan-rate. The chemical composition of the catalysts was examined through energy-dispersive X-ray (EDX) spectroscopy conducted on a JEOL JSM 6010LA scanning electron microscope (SEM) (Akishima, Tokyo, Japan). Each catalyst surface was examined twice applying two different accelerating voltages: $10 \mathrm{kV}$ and $20 \mathrm{kV}$. The different accelerating voltages change the interaction volume resulting from the electron beam-sample surface interaction. Thus, applying two different voltages enables the composition at two different depths to be studied [51]. Transmission electron microscopy (TEM) was undertaken to examine the catalyst surface morphology using a Phillips C100 microscope (Hillsboro, OR, USA) operating at $100 \mathrm{kV}$ and equipped with a LaB6 filament. X-ray photoelectron spectroscopy (XPS) was applied to investigate the metal oxidation state and surface composition of the prepared electrocatalysts. A Thermo Scientific K-Alpha ${ }^{+}$spectrometer (Waltham, MA, USA) equipped with an Al-X ray source $(72 \mathrm{~W})$ was used. The pass energy to record the data was $150 \mathrm{eV}$ for survey scans and $40 \mathrm{eV}$ for high-resolution scans. The survey scan step size is $1 \mathrm{eV}$, and that of the high-resolution scans is $0.1 \mathrm{eV}$. Low-energy electrons and argon ions were used to neutralize the charge. CasaXPS (Teignmouth, UK) was used to analyze the data implementing a Shirley-type background and Scofield crosssections with an energy dependence of -0.6 .

The catalysts were evaluated for EOR via cyclic voltammetry (CV), chronoamperometry (CA), and electrochemical impedance spectroscopy (EIS). For this, a 3-electrode half-cell was used in which the working electrode is a glassy carbon electrode $(\mathrm{GCE}, \varnothing 3 \mathrm{~mm})$ coated with each catalyst ink. The reference and counter electrodes were $\mathrm{Ag} / \mathrm{AgCl}$ (sat' KCL) and $\mathrm{Pt}$ wire, respectively. The applied potential is converted to normal hydrogen electrode 
(NHE). A Gamry 600 portable Station from Gamry Instruments Inc. (Warminster, PA, USA) was used to perform the electrochemical evaluation. The catalyst ink was prepared by dispersing $5 \mathrm{mg}$ of its powder in $25 \mu \mathrm{L}$ (Nafion ${ }^{\circledR} 117,5 \%$ ) and $2000 \mu \mathrm{L}$ of ethanol $(100 \%)$ The mixture was then sonicated for $1 \mathrm{~h}$. Before drop-casting the working electrode with ink, it was polished with alumina powder ( 1 and $0.05 \mu \mathrm{m}$, respectively) to produce a mirror-like surface. Then, $25 \mu \mathrm{L}$ of the ink was painted on GCE at $5 \mu \mathrm{L}$ intervals.

\section{Results}

\subsection{Physical Characterization}

X-ray Diffraction (XRD)

Figure 1 shows the XRD patterns of $\mathrm{Pd} / \mathrm{C}, \mathrm{Ni} / \mathrm{C}, \mathrm{Ag} / \mathrm{C}, \mathrm{PdAgNi} / \mathrm{C}$, and $\mathrm{Pd}_{4} \mathrm{Ag}_{2} \mathrm{Ni}_{1} / \mathrm{C}$. The $25^{\circ}$ peak present in all patterns is attributed to the semi-crystalline graphitic nature of Vulcan carbon. For the Ni pattern, the metal peaks are of lower intensity than the carbon peaks as $\mathrm{Ni}$ is present in the form of hydroxide and oxide, indicated by peaks at $34^{\circ}, 60^{\circ}$, and $42.5^{\circ}$, respectively. The Ag pattern, on the other hand, shows the (111), (200), (231), (220), and (311) reflections at $38^{\circ}, 44^{\circ}, 46^{\circ}, 65^{\circ}$, and $77^{\circ}$, respectively resembling a face-centered cubic Ag (JCPDS card, File No. 04-0783) [52]. A similar Ag pattern has been obtained previously [31]. The Pd pattern presents (111), (200), (220), and (311) reflections located at $39.8^{\circ}, 46^{\circ}, 76.7^{\circ}$, and $82.2^{\circ}$ indicative of Pd (JCPDS card, File No. 46-1043). Considering the XRD patterns of both trimetallic samples, it can be noted that a significant peak overlapping occurs. The high intensity peaks present at lower-angles align well with the pure Ag peak positions, whereas the lower-intensity, broader, peaks at higher-angles align with the peak positions of $\mathrm{Pd}$. Monometallic $\mathrm{Ni} / \mathrm{C}$ shows $\mathrm{Ni}(\mathrm{OH})_{2}$ and $\mathrm{Ni}$ (111) peaks at $34.5^{\circ}, 60.1^{\circ}$, and $42.7^{\circ}$, respectively.

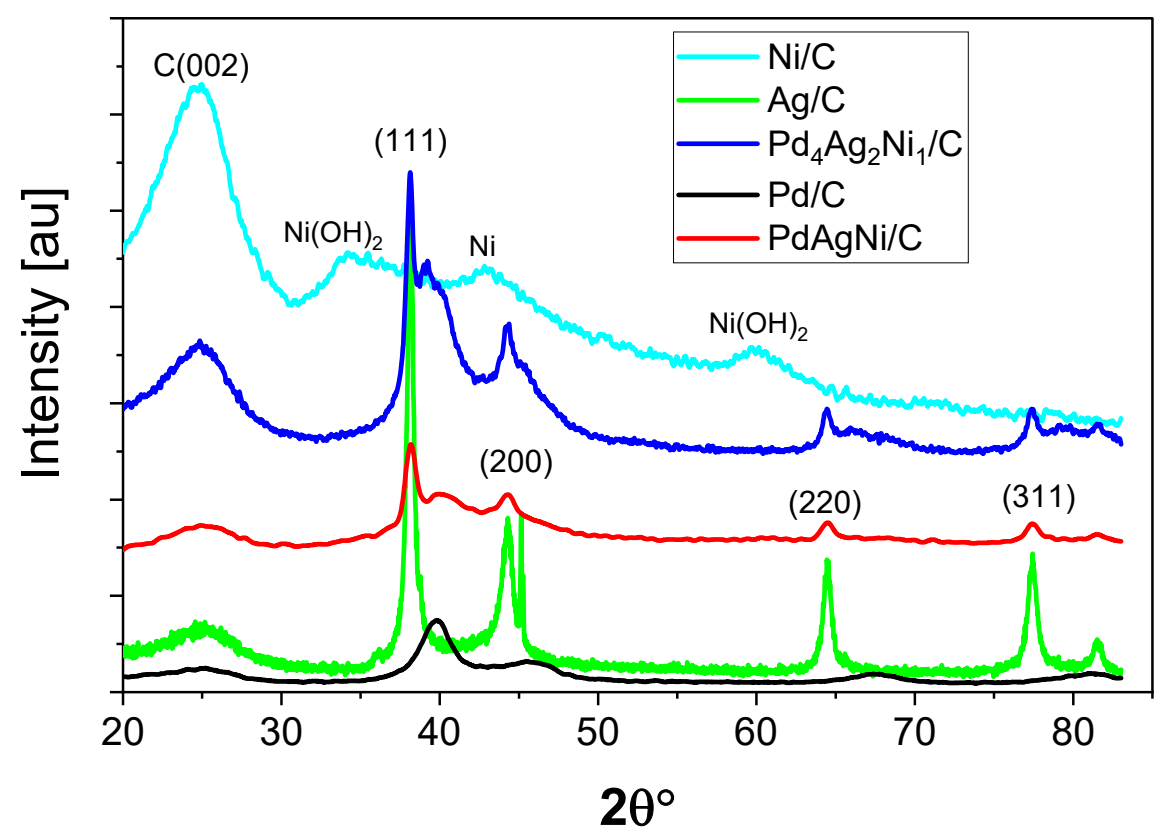

Figure 1. X-ray diffraction patterns of $\mathrm{Pd} / \mathrm{C}, \mathrm{Ag} / \mathrm{C}, \mathrm{Ni} / \mathrm{C}, \mathrm{PdAgNi} / \mathrm{C}$, and $\mathrm{Pd}_{4} \mathrm{Ag}_{2} \mathrm{Ni}_{1} / \mathrm{C}$.

\subsection{Energy Dispersive X-ray Spectroscopy (EDX)}

Table 2 lists the elemental metal molar and weight compositional ratios of $\mathrm{PdAgNi} / \mathrm{C}$ and $\mathrm{Pd}_{4} \mathrm{Ag}_{2} \mathrm{Ni}_{1} / \mathrm{C}$. While the average total metal loading of $\mathrm{Pd}_{4} \mathrm{Ag}_{2} \mathrm{Ni}_{1} / \mathrm{C}$ as measured by EDX is close to the theoretical loading at $12 \mathrm{wt} . \%$, it is slightly higher (16 wt. \%) in the case of $\mathrm{PdAgNi} / \mathrm{C}$. As EDX is a surface-weighted technique, this indicates the preferential distribution of metal in the surface region of the catalyst. Furthermore, higher Ni atomic concentrations are observed at $10 \mathrm{kV}$ than at $20 \mathrm{kV}$ indicating the preference of $\mathrm{Ni}$ to be distributed in the near-surface region. 
Table 2. EDX elemental metal composition of $\mathrm{PdAgNi} / \mathrm{C}$ and $\mathrm{Pd}_{4} \mathrm{Ag}_{2} \mathrm{Ni}_{1} / \mathrm{C}$ detected at $20 \mathrm{kV}$ and $10 \mathrm{kV}$ voltages.

\begin{tabular}{|c|c|c|c|c|c|c|c|c|}
\hline \multirow{2}{*}{ Catalyst } & \multirow{2}{*}{ Acc. Voltage } & \multicolumn{2}{|c|}{ Pd } & \multicolumn{2}{|c|}{$\mathrm{Ni}$} & \multicolumn{2}{|c|}{ Ag } & \multirow{2}{*}{ Tot. Metal Wt. \% } \\
\hline & & Wt. \% * & At. $\% * *$ & Wt. $\%$ & At. $\%$ & Wt. \% & At. $\%$ & \\
\hline \multirow{2}{*}{$\mathrm{Pd}_{4} \mathrm{Ag}_{2} \mathrm{Ni}_{1} / \mathrm{C}$} & $10 \mathrm{kV}$ & 7.89 & 1.02 & 1.64 & 0.38 & 1.98 & 0.25 & 11.51 \\
\hline & $20 \mathrm{kV}$ & 8.28 & 1.09 & 1.10 & 0.26 & 3.26 & 0.42 & 12.46 \\
\hline \multirow{2}{*}{$\mathrm{PdAgNi} / \mathrm{C}$} & $10 \mathrm{kV}$ & 6.47 & 0.88 & 7.68 & 1.90 & 3.39 & 0.46 & 17.54 \\
\hline & $20 \mathrm{kV}$ & 6.92 & 0.94 & 5.04 & 1.24 & 4.10 & 0.55 & 16.06 \\
\hline
\end{tabular}

* wt. \%: weight percentage \%; ** at. \%: atomic percentage $\%$.

The PdAgNi/C surface can therefore be considered as relatively rich in Ni, while for $\mathrm{Pd}_{4} \mathrm{Ag}_{2} \mathrm{Ni}_{1} / \mathrm{C}$ the $\mathrm{Ni}$ content in the surface region is comparable to that of $\mathrm{Ag}$ even though the theoretical Ni quantity in the bulk sample is half of that of Ag. Figure 2 shows the elemental EDX maps of $\mathrm{Pd}, \mathrm{Ni}, \mathrm{Ag}$, and $\mathrm{C}$ in both $\mathrm{PdAgNi} / \mathrm{C}$ and $\mathrm{Pd}_{4} \mathrm{Ag}_{2} \mathrm{Ni}_{1} / \mathrm{C}$. Examining the maps of $\mathrm{Pd}_{4} \mathrm{Ag}_{2} \mathrm{Ni}_{1} / \mathrm{C}(\mathrm{A}-\mathrm{D})$ shows that the carbon support and metal species are evenly dispersed across the catalyst surface.
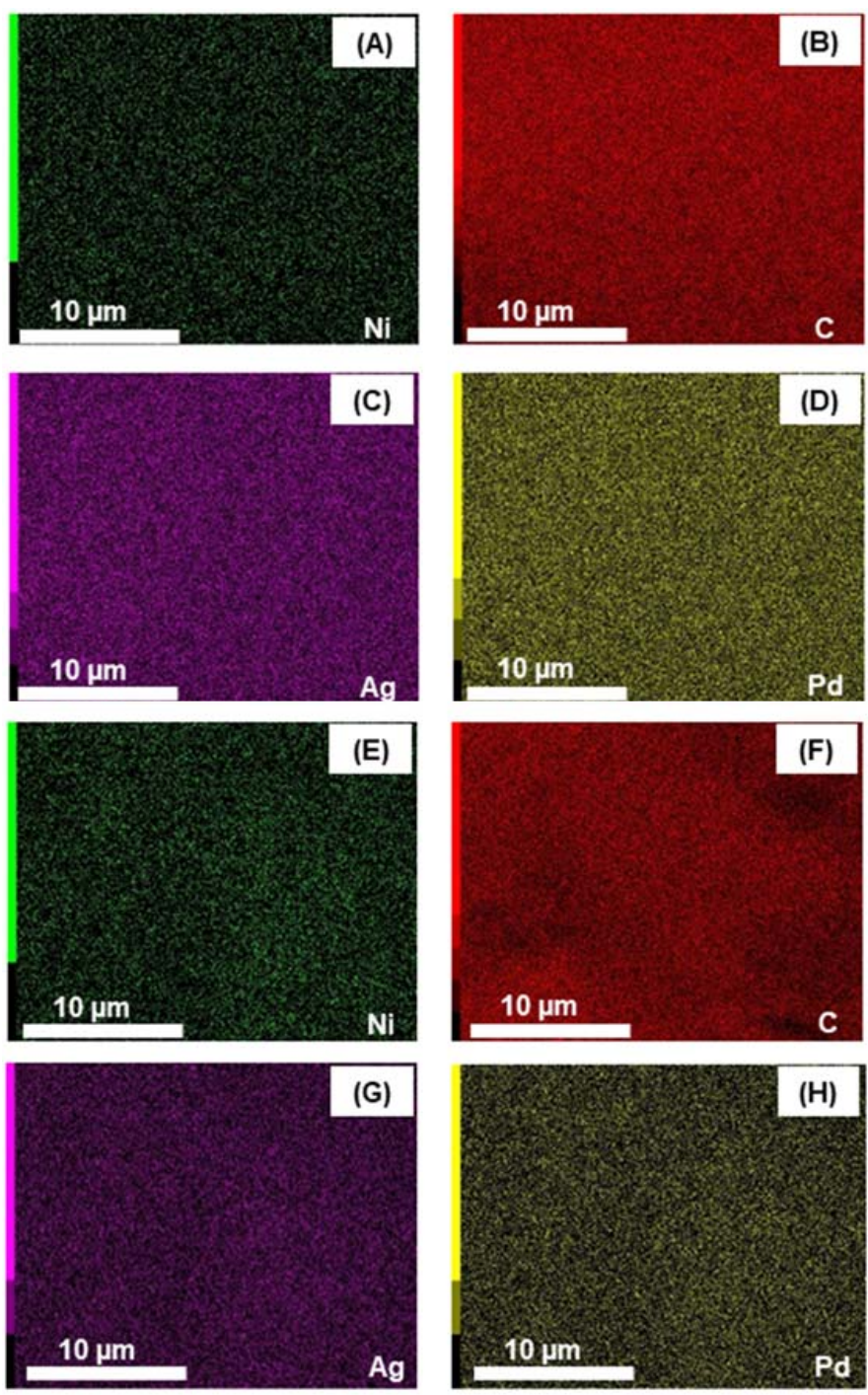

Figure 2. EDS elemental maps of $\mathrm{Pd}_{4} \mathrm{Ag}_{2} \mathrm{Ni}_{1} / \mathrm{C}(\mathbf{A}-\mathbf{D})$ and $\mathrm{PdAgNi} / \mathrm{C}(\mathbf{E}-\mathbf{H})$ taken at $10 \mathrm{kV}$.

\subsection{Transmission Electron Microscopy (TEM)}

Figure 3 shows TEM micrographs $(\mathrm{A}, \mathrm{C}, \mathrm{D})$ of $\mathrm{Pd} / \mathrm{C}, \mathrm{Pd}_{4} \mathrm{Ag}_{2} \mathrm{Ni}_{1} / \mathrm{C}$, and $\mathrm{PdAgNi} / \mathrm{C}$. The respective particle size distribution is, also, shown $(B, D, F)$. From inspection of the 
$\mathrm{Pd} / \mathrm{C}$ micrograph, it can be noted that Pd nanoparticles (average size $6.7 \mathrm{~nm}$ ) are dispersed over larger carbon aggregates $(40-60 \mathrm{~nm})$. Additionally, some particle agglomeration can be noted. The particle size distribution was measured by manually selecting the metal particles through use of ImageJ software. The average particle size and standard deviation of $\mathrm{Pd} / \mathrm{C}$ are 6.7 and $5 \mathrm{~nm}$, respectively. The high standard deviation value is suggestive of the high variation in particle size as a consequence of high particle agglomeration. In contrast, the average particle size of $\mathrm{Pd}_{4} \mathrm{Ag}_{2} \mathrm{Ni}_{1} / \mathrm{C}$ is $5.6 \mathrm{~nm}$ and the standard deviation to $2.7 \mathrm{~nm}$. This is possibly due to the contradicting forces that affect the particle aggregation during both nucleation and growth. It is extensively reported that preparing multi-metallic samples results in different attraction and repulsion forces and, therefore, smaller particle sizes $[22,24,41,53-56]$. The same trend is noted in PdAgNi, which has a smaller total quantity of $\mathrm{Pd}$; in this case the average particle size and standard deviations are $4.4 \mathrm{~nm}$ and $3 \mathrm{~nm}$, respectively.
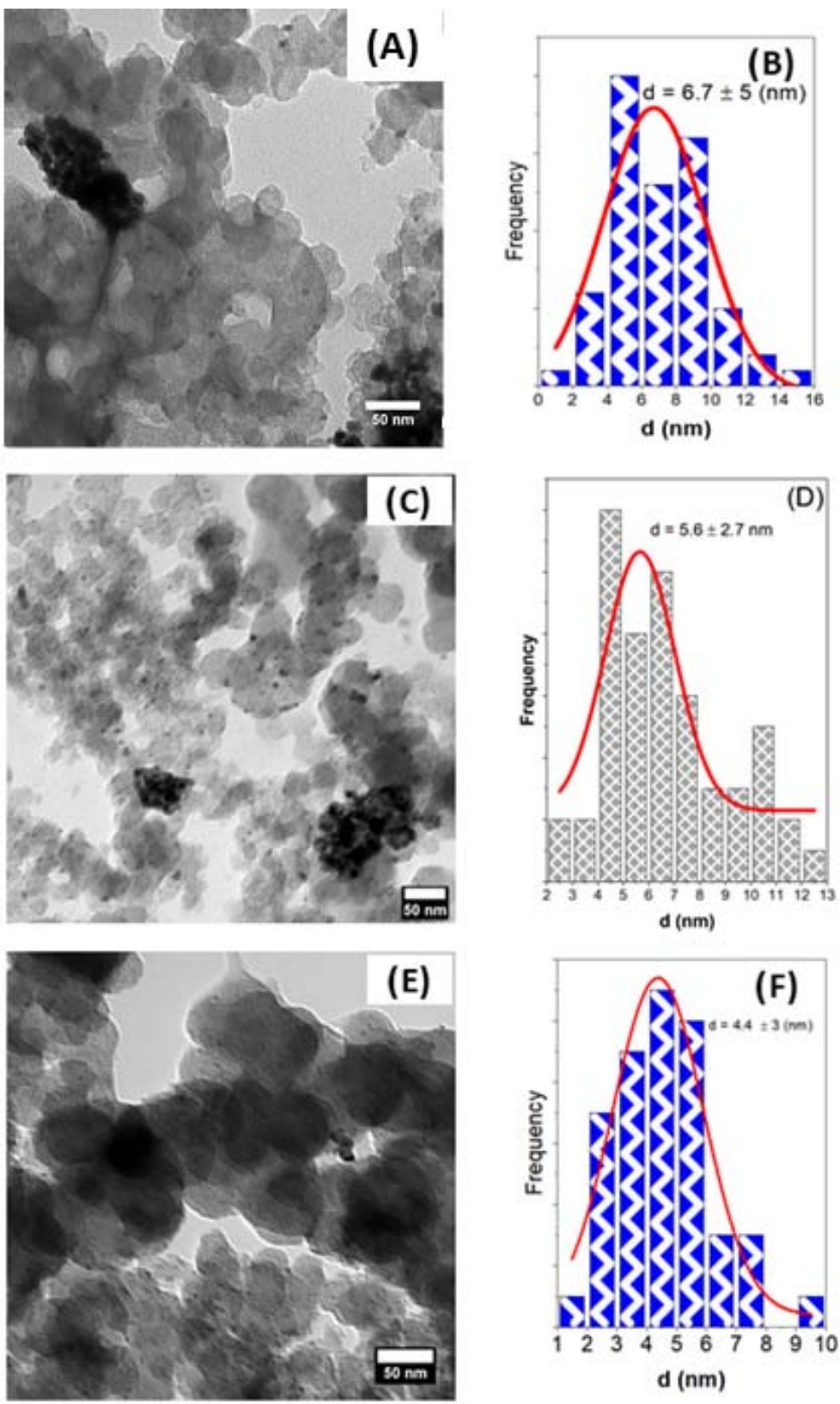

Figure 3. TEM Micrographs and the respective particle size distribution of $\mathrm{Pd} / \mathrm{C}(\mathbf{A}, \mathbf{B}), \mathrm{Pd}_{4} \mathrm{Ag}_{2} \mathrm{Ni}_{1} / \mathrm{C}$ (C,D), and PdAgNi/C (E,F). 


\subsection{X-ray Photoelectron Spectroscopy (XPS)}

XPS analysis was undertaken to investigate the metal oxidation state and surface composition of the samples. Figure 4 shows the XPS full survey scans of $\mathrm{Pd} / \mathrm{C}, \mathrm{PdAgNi} / \mathrm{C}$, and $\mathrm{Pd}_{4} \mathrm{Ag}_{2} \mathrm{Ni}_{1} / \mathrm{C}$. The $\mathrm{C} 1 \mathrm{~s}, \mathrm{Pd} 3 \mathrm{~d}, \mathrm{Ag} 3 \mathrm{~d}, \mathrm{Pd} 3 \mathrm{p}$ (overlapping with $\mathrm{O} 1 \mathrm{~s}$ ), and $\mathrm{Ni} 2 \mathrm{p}$ are located approximately at 284, 335, 370,532, and $856 \mathrm{eV}$, respectively.

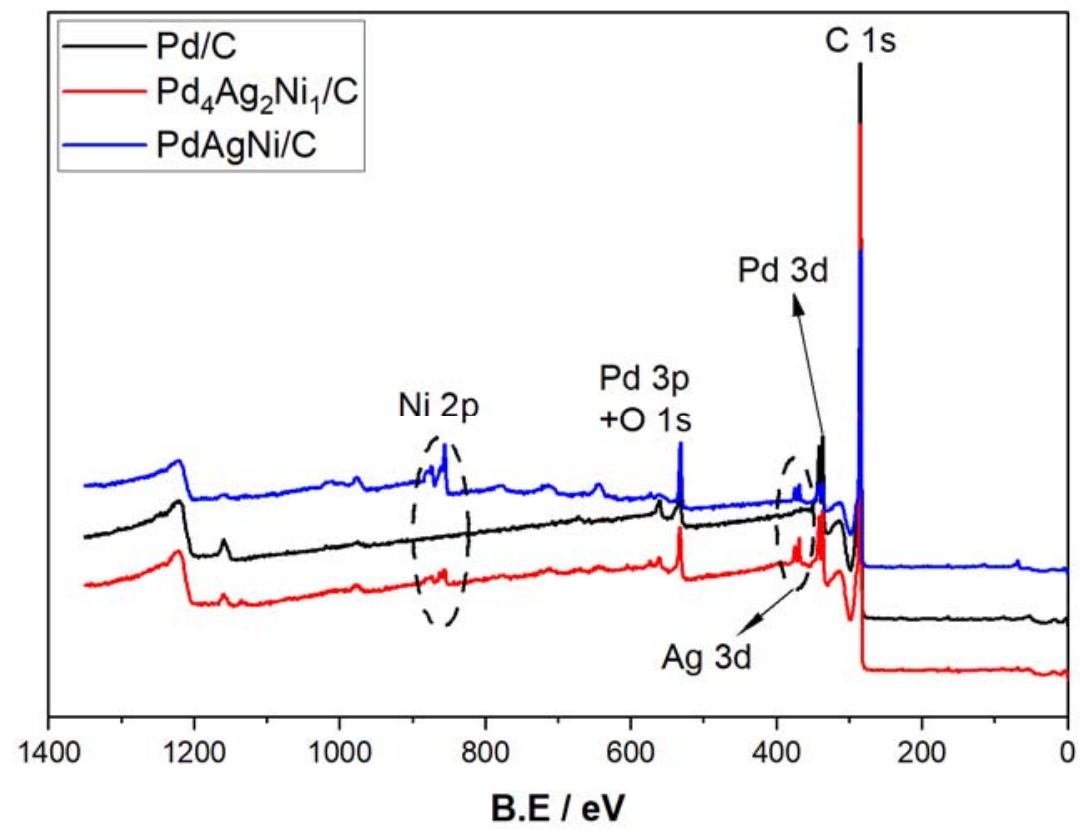

Figure 4. XPS full surveys of $\mathrm{Pd} / \mathrm{C}, \mathrm{Pd}_{4} \mathrm{Ag}_{2} \mathrm{Ni}_{1} / \mathrm{C}$, and $\mathrm{PdAgNi} / \mathrm{C}$.

Figure 5 shows the detailed elemental peaks of $\mathrm{Pd} 3 \mathrm{~d}, \mathrm{Ag} 3 \mathrm{~d}$, and $\mathrm{Ni} 2 \mathrm{p}$ in $\mathrm{Pd} / \mathrm{C}$, $\mathrm{Pd}_{4} \mathrm{Ag}_{2} \mathrm{Ni}_{1} / \mathrm{C}$, and $\mathrm{PdAgNi} / \mathrm{C}$. The $\mathrm{Pd} 3 \mathrm{~d}$ of $\mathrm{Pd} / \mathrm{C}(\mathrm{A})$ is deconvoluted into a high-energy band $(340.4 \mathrm{eV})$ of $\mathrm{Pd} 3 \mathrm{~d}_{3 / 2}$ and a low-energy band $(335.48 \mathrm{eV})$ of $\mathrm{Pd} 3 \mathrm{~d}_{5 / 2}$. Additionally, the PdO peaks are visible around $342 \mathrm{eV}$ and $337 \mathrm{eV}$. Table 3 lists the XPS surface concentrations of $\mathrm{C}, \mathrm{O}, \mathrm{Pd}, \mathrm{Ag}$, and $\mathrm{Ni}$ for the three samples. The XPS surface concentration $\mathrm{Pd}$ of $\mathrm{Pd} / \mathrm{C}$ is 1.63 At. $\%$ and $0.45 \%$ for $\mathrm{Pd}^{0}$ and $\mathrm{Pd}^{2+}$, respectively. The presence of $\mathrm{Pd}$ oxide is indicative of $\mathrm{Pd}$ air instability which could be improved by adding another metal. $\mathrm{PdAgNi} / \mathrm{C}$ also presents a significant fraction of $\mathrm{Pd}^{2+}-16 \%$ of the total Pd present. $\mathrm{Pd}_{4} \mathrm{Ag}_{2} \mathrm{Ni}_{1} / \mathrm{C}$ however, with a lower overall $\mathrm{Pd}$ content, presents only metallic $\mathrm{Pd}^{0}$, as shown in Figure 5D. The $\mathrm{Ag} 3 \mathrm{~d}$ double-peak is located at 374 and $368 \mathrm{eV}$ for $3 \mathrm{~d}_{3 / 2}$ and $3 \mathrm{~d}_{5 / 2}$ (Figure $5 \mathrm{E}$ ), respectively. The Ni $2 p$ peaks of $\mathrm{Ni}^{0}$ and $\mathrm{Ni}^{+2}$ of $\mathrm{Pd}_{4} \mathrm{Ag}_{2} \mathrm{Ni}_{1} / \mathrm{C}$ are present at 852,856 , and $862 \mathrm{eV}$ (Figure 5D), respectively, with no visible satellite peaks. The Ni XPS surface concentration of that sample is 0.05 at. \% (for metallic $\mathrm{Ni}$ ) and 0.73 at. \% (for $\mathrm{Ni}(\mathrm{OH})_{2}$ ).

Table 3. XPS surface atomic concentration of $\mathrm{C}, \mathrm{O}, \mathrm{Pd}, \mathrm{Ag}$, and $\mathrm{Ni}$ in $\mathrm{Pd} / \mathrm{C}, \mathrm{Pd}_{4} \mathrm{Ag}_{2} \mathrm{Ni}_{1} / \mathrm{C}$, and $\mathrm{PdAgNi} / \mathrm{C}$.

\begin{tabular}{|c|c|c|c|c|c|c|c|c|}
\hline \multirow[t]{2}{*}{ Catalyst } & \multirow{2}{*}{ C At. $\%$} & \multirow{2}{*}{$\mathrm{O}$ at. $\%$} & \multicolumn{2}{|c|}{ Pd at. $\%$} & \multirow{2}{*}{ Ag at. $\%$} & \multicolumn{2}{|c|}{$\mathrm{Ni}$ at. $\%$} & \multirow{2}{*}{ Pd:Ag:Ni Ratio } \\
\hline & & & $\mathrm{Pd}^{0}$ & $\mathbf{P d}^{2+}$ & & $\mathrm{Ni}^{0}$ & $\mathrm{Ni}^{2+}$ & \\
\hline $\mathrm{Pd} / \mathrm{C}$ & 96.13 & 1.78 & 1.63 & 0.45 & & & & \\
\hline $\mathrm{Pd}_{4} \mathrm{Ag}_{2} \mathrm{Ni}_{1} / \mathrm{C}$ & 93.91 & 3.14 & 1.59 & 0 & 0.4 & 0.05 & 0.73 & $4: 1: 2$ \\
\hline PdAgNi/C & 92.15 & 4.69 & 0.64 & 0.12 & 0.32 & 0 & 2.01 & 2.7: 1:6.7 \\
\hline
\end{tabular}



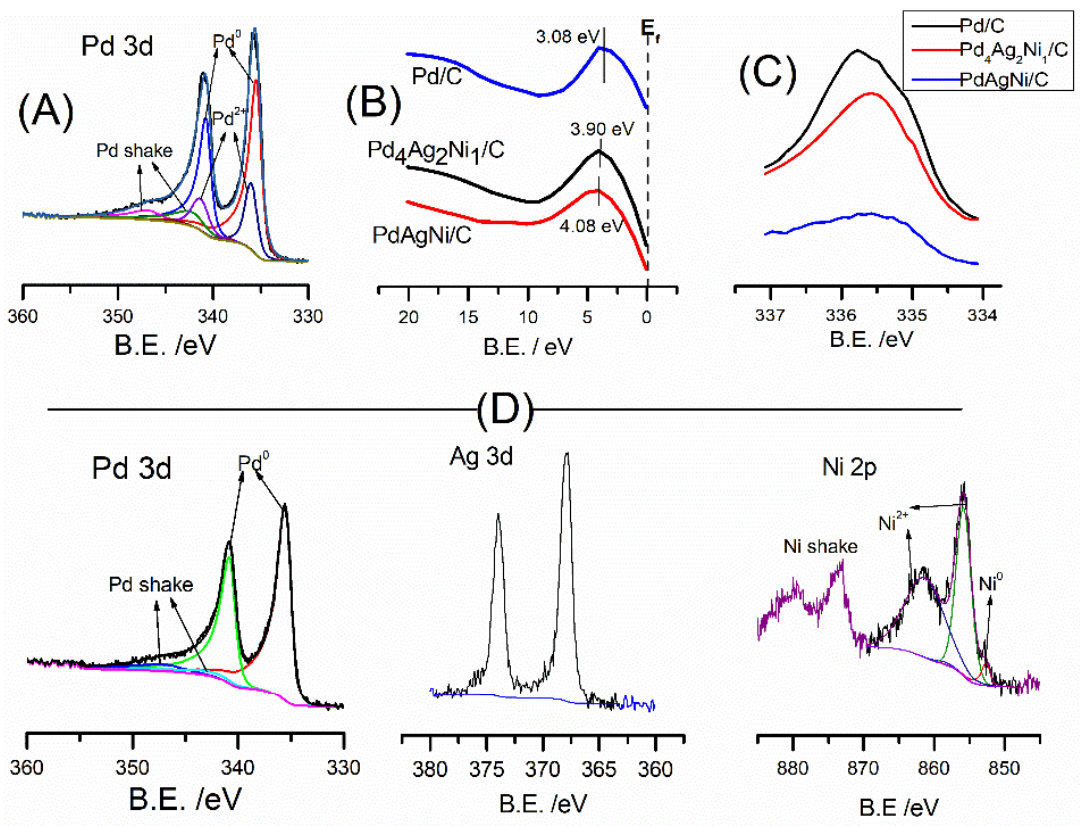

(E)

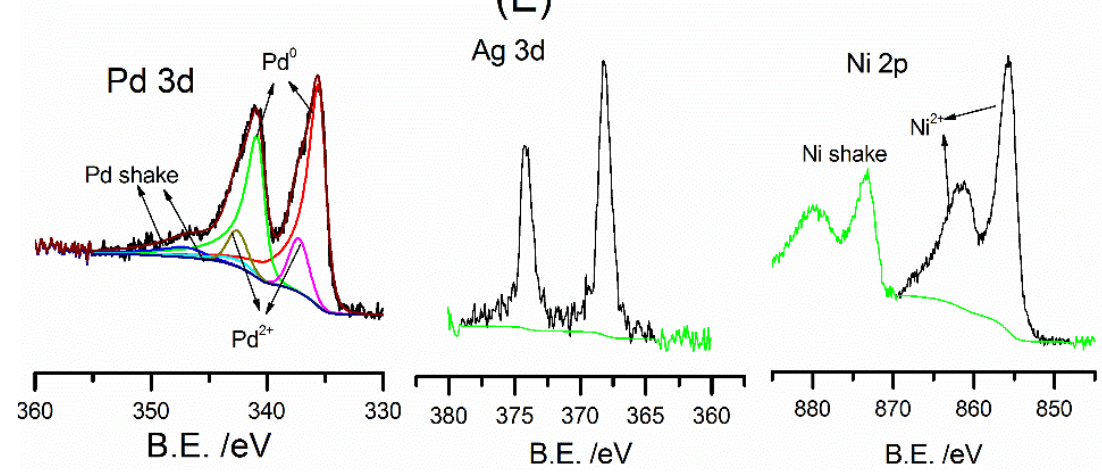

Figure 5. XPS elemental peaks of $\mathrm{Pd} 3 \mathrm{~d}$ in in $\mathrm{Pd} / \mathrm{C}(\mathbf{A})$, valence band spectra $(\mathbf{B})$ and $\mathrm{Pd} 3 \mathrm{~d}_{5 / 2}(\mathbf{C})$ of $\mathrm{Pd} / \mathrm{C}, \mathrm{Pd}_{4} \mathrm{Ag}_{2} \mathrm{Ni}_{1} / \mathrm{C}$, and PdAgNi/C, Pd 3d, Ag 3d, Ni 2p, of $\mathrm{Pd}_{4} \mathrm{Ag}_{2} \mathrm{Ni}_{1} / \mathrm{C}$ (D) and PdAgNi/C (E).

\subsection{Electrochemical Evaluation}

Figure 6 shows the cyclic voltammograms of $\mathrm{Pd} / \mathrm{C}, \mathrm{PdAgNi} / \mathrm{C}$, and $\mathrm{Pd}_{4} \mathrm{Ag}_{2} \mathrm{Ni}_{1} / \mathrm{C}$ performed in $1 \mathrm{M} \mathrm{KOH}$ at $50 \mathrm{mV} / \mathrm{s}$. It is noteworthy that the thinnest profile is observed for $\mathrm{Pd} / \mathrm{C}$. This is indicative of a thinner double-layer, and consequently, faster charging/discharging behavior for Pd/C [42]. As Pd is known to absorb hydrogen within its bulk, the $\mathrm{H}_{\mathrm{abs}}$ /ads peak in the forward scan at -600 mV is not present. This peak is, however, more pronounced on both trimetallic samples, which may be ascribed to the presence of Ag. Upon increasing the potential, the $\mathrm{OH}$ adsorption peak between -400 and $-200 \mathrm{mV}$ is more apparent for monometallic $\mathrm{Pd} / \mathrm{C}$ than for the trimetallic samples. $\mathrm{OH}$ adsorption can be considered as the onset of surface oxidation, however oxidation of Pd commences at approximately $0.0 \mathrm{mV}$ vs. NHE. Ag surface oxidation is noted at $\sim 470 \mathrm{mV}$ followed by Ni oxidation up to the scan end at $600 \mathrm{mV}$. Both $\mathrm{Ni}$ and $\mathrm{Ag}$ oxidation peaks are more pronounced for $\mathrm{PdAgNi} / \mathrm{C}$ than for $\mathrm{Pd}_{4} \mathrm{Ag}_{2} \mathrm{Ni}_{1} / \mathrm{C}$ as the former contains higher quantities of $\mathrm{Ni}$ and $\mathrm{Ag}$. In the reverse scan, distinctive reduction peaks for $\mathrm{Ni}$, $\mathrm{Ag}$, and $\mathrm{Pd}$ appear at 450, 220, and $-200 \mathrm{mV}$, respectively. A small shoulder on the $\mathrm{Pd}$ reduction peak is noted for $\mathrm{Pd}_{4} \mathrm{Ag}_{2} \mathrm{Ni}_{1} / \mathrm{C}$ and $\mathrm{Pd} / \mathrm{C}$ which is not clear for $\mathrm{PdAgNi} / \mathrm{C}$. This is likely to be reflective of the reduction of different $\mathrm{Pd}$ oxides. 


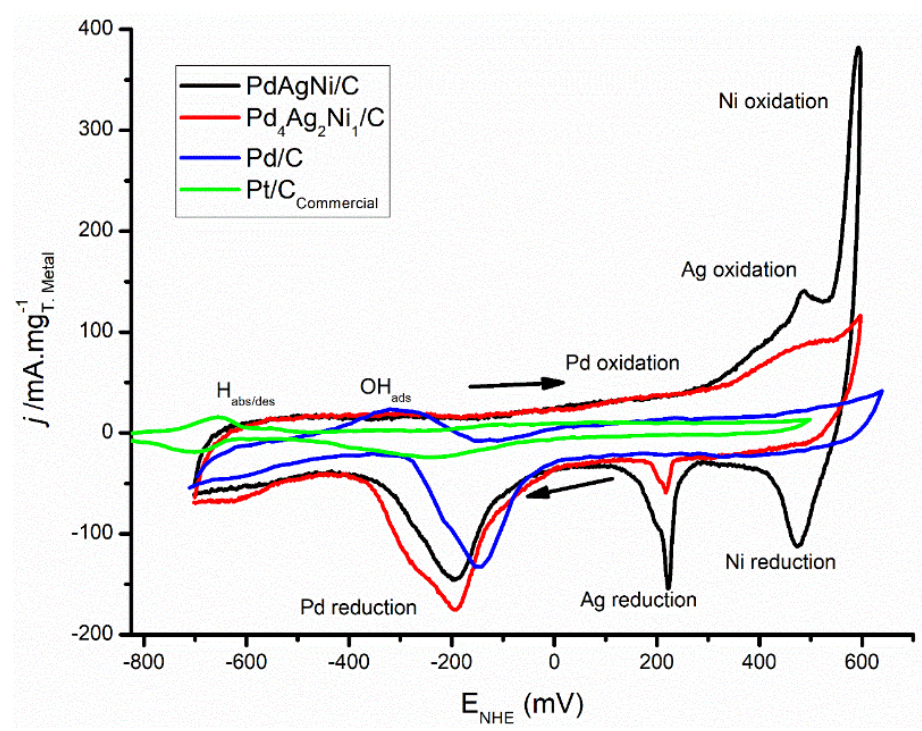

Figure 6. $\mathrm{CV}$ voltammograms of $\mathrm{Pd} / \mathrm{C}, \mathrm{Pd}_{4} \mathrm{Ag}_{2} \mathrm{Ni}_{1} / \mathrm{C}$, and $\mathrm{PdAgNi} / \mathrm{C}$ in $1 \mathrm{M} \mathrm{KOH}$ at $50 \mathrm{mV} / \mathrm{s}$.

Figure 7 shows the cyclic voltammograms of the three catalysts in $1 \mathrm{M} \mathrm{KOH}+\mathrm{EtOH}$ at $50 \mathrm{mV}$. The addition of ethanol suppresses the $\mathrm{H}_{\text {ands/abs }}$ peak as reported elsewhere $[55,57]$. With the start of $\mathrm{OH}$ adsorption, adsorbed ethoxy species undergo oxidation and are removed from $\mathrm{Pd}$ sites, thereby making these sites available for further fuel oxidation. As the adsorbed $\mathrm{OH}$ increases with increasing potential, the free $\mathrm{Pd}$ sites increase, and an increasing current is drawn. While the onset oxidation potential in case of $\mathrm{Pd} / \mathrm{C}$ is $-390 \mathrm{mV}$, it is shifted to $-500 \mathrm{mV}$ in case of $\mathrm{PdAgNi} / \mathrm{C}$ and $\mathrm{Pd}_{4} \mathrm{Ag}_{2} \mathrm{Ni}_{1} / \mathrm{C}$ which suggests a reduction in the activation barrier against ethanol oxidation on the surface of both trimetallic samples. A similar shift in potential is noted for the oxidation peak on PdAgNi sample compared to $\mathrm{Pd}$. The peak current density in case of $\mathrm{PdAgNi} / \mathrm{C}\left(2700 \mathrm{~mA} / \mathrm{m}_{\mathrm{gPd}}\right)$ is higher than $\mathrm{Pd}_{4} \mathrm{Ag}_{2} \mathrm{Ni}_{1} / \mathrm{C}\left(2300 \mathrm{~mA} / \mathrm{m}_{\mathrm{gPd}}\right)$ and the smallest peak current density is of $\mathrm{Pd} / \mathrm{C}\left(1.8 \mathrm{~A} / \mathrm{m}_{\mathrm{gPd}}\right)$.

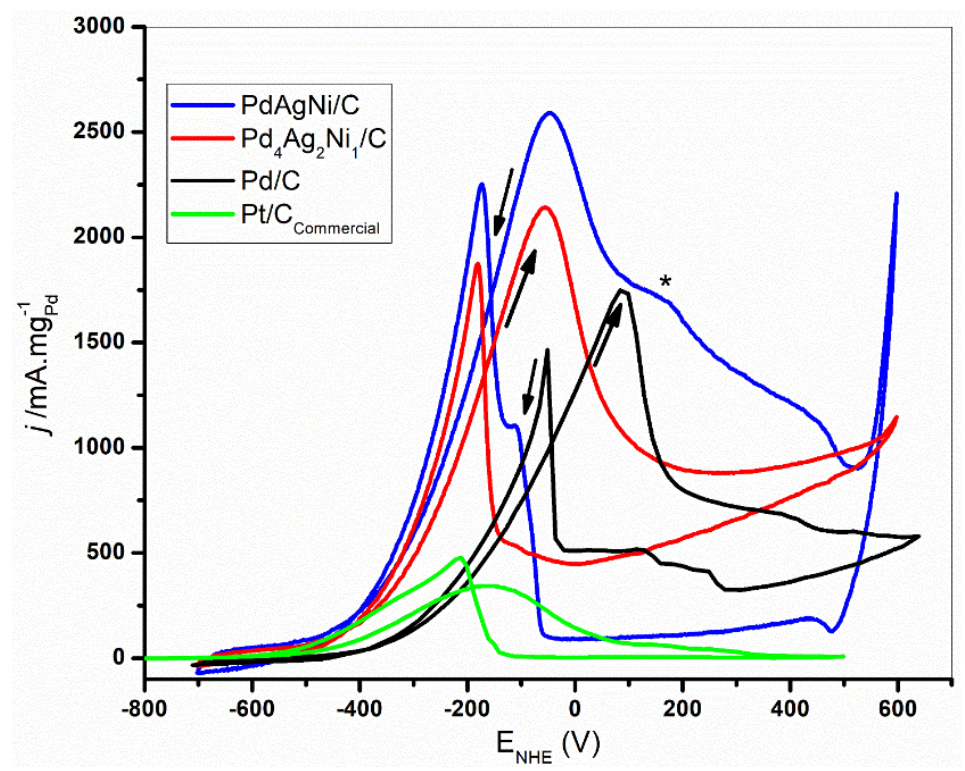

Figure 7. $\mathrm{CV}$ Voltammograms of $\mathrm{Pd} / \mathrm{C}, \mathrm{Pd}_{4} \mathrm{Ag}_{2} \mathrm{Ni}_{1} / \mathrm{C}$, and $\mathrm{Pd} / \mathrm{C}$ in $1 \mathrm{M} \mathrm{KOH}+\mathrm{EtOH}$ at $50 \mathrm{mV} / \mathrm{s}$.

When the catalyst surface can no longer adsorb $\mathrm{OH}$, the surface $\mathrm{Pd}$ oxides thereby decreasing the number of $\mathrm{Pd}$ active sites as the potential increases. This ultimately decreases the drawn current up to the end of the forward scan. It is noteworthy that around the forward current peak, the reactants are depleted much faster than at the beginning of the 
scan [8]. A shoulder peak is noted on $\mathrm{PdAgNi} / \mathrm{C}$ at $200 \mathrm{mV}$ which may be suggestive of the oxidation of ethoxy intermediates on Pd. At the end of the PdAgNi forward scan, a sharp current rise is noted due to the Ni oxidation that also appears in the voltammogram conducted in the absence of ethanol. The sharp peak in the inverse scan is due to the removal of the incompletely oxidized intermediates from EOR and recovery of Pd active sites. It is noteworthy that the forward sweep current peak is higher than the reverse one on all catalysts which is a positive indication of the ability of the catalyst to tolerate poisoning species $[58,59]$. Therefore, CO-like species are less likely to block further EOR on the catalysts developed in the present work.

Figure 8 shows the chronoamperometric scans of $\mathrm{Pd} / \mathrm{C}, \mathrm{Pd}_{4} \mathrm{Ag}_{2} \mathrm{Ni}_{1} / \mathrm{C}$, and $\mathrm{PdAgNi} / \mathrm{C}$ performed at fixed potentials of $-300 \mathrm{mV}$ and $+100 \mathrm{mV}$ vs. NHE. The former was chosen because it is in the middle of the window in which $\mathrm{OH}$ was adsorbed causing the oxidation and removal of ethoxy species from Pd surface. The latter was chosen because it is greater than the potential at which the Pd surface oxidation starts. These data show that the CA current density of $\mathrm{PdAgNi} / \mathrm{C}$ sample - though higher than that of $\mathrm{Pd}_{4} \mathrm{Ag}_{2} \mathrm{Ni}_{1} / \mathrm{C}$ at the two CA steps-decays much faster at the higher-potential $(+0.1 \mathrm{~V})$ to the extent that it drops below $\mathrm{Pd}_{4} \mathrm{Ag}_{2} \mathrm{Ni}_{1} / \mathrm{C}$ towards the end of the CA duration. According to EDX and $\mathrm{XPS}$, the surface of $\mathrm{PdAgNi} / \mathrm{C}$ is Ni-rich and correspondingly deficient in $\mathrm{Pd}$ and $\mathrm{Ag}$. $\mathrm{PdAgNi} / \mathrm{C}$, therefore, presents fewer accessible Pd surface sites for EOR than Pd/C or $\mathrm{Pd}_{4} \mathrm{Ag}_{2} \mathrm{Ni}_{1} / \mathrm{C}$. During the high-potential CA scan, the number of available Pd sites further decreases through site poisoning via the strong adsorption of EOR intermediates. The $\mathrm{PdAgNi}$ voltammograms (Figures 6 and 7) show that $\mathrm{OH}$ adsorption does not continue at $+0.1 \mathrm{~V}$. Therefore, at high potential, $\mathrm{PdAgNi} / \mathrm{C}$ is susceptible to poisoning by carbonaceous species from EOR. In contrast, $\mathrm{Pd}_{4} \mathrm{Ag}_{2} \mathrm{Ni}_{1} / \mathrm{C}$ generates a steadier $\mathrm{CA}$ current density than $\mathrm{PdAgNi} / \mathrm{C}$ at $+0.1 \mathrm{~V}$; which is ascribed to the higher concentration of $\mathrm{Pd}$ in the surface region for the former, providing a greater number of available $\mathrm{Pd}$ sites and hence greater resistance to poisoning. $\mathrm{Pd} / \mathrm{C}$ achieves an intermediate current decay between $\mathrm{PdAgNi} / \mathrm{C}$ and $\mathrm{Pd}_{4} \mathrm{~A}_{2} 2 \mathrm{Ni}_{1} / \mathrm{C}$ which could be explained by two factors: the strong adsorption of CO-like species and the abundance of Pd surface sites.

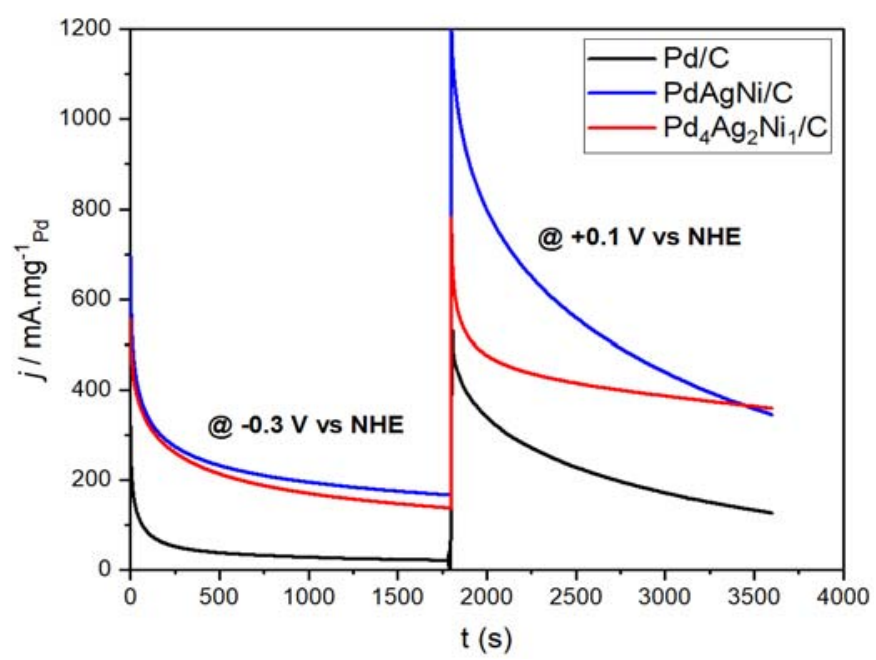

Figure 8. Chronoamperometric (CA) scans of $\mathrm{Pd} / \mathrm{C}, \mathrm{Pd}_{4} \mathrm{Ag}_{2} \mathrm{Ni}_{1} / \mathrm{C}, \mathrm{PdAgNi} / \mathrm{C}$ at $-0.3 \mathrm{~V}$ and $+0.1 \mathrm{~V}$ vs. NHE.

Figure 9 shows the EIS spectra of $\mathrm{Pd}_{4} \mathrm{Ag}_{2} \mathrm{Ni}_{1} / \mathrm{C}$, and $\mathrm{PdAgNi} / \mathrm{C}$ recorded at $-0.3 \mathrm{~V}$, $0.0 \mathrm{~V}$, and $+0.3 \mathrm{~V}$ vs. NHE between $10,000 \mathrm{~Hz}$ and $0.1 \mathrm{~Hz}$ while the voltage amplitude is $5 \mathrm{mV}$. Each experiment was preceded with a 10-min potentiostatic scan to compensate for the current perpetuation. EIS spectra at $-0.3 \mathrm{~V}$ and $0.0 \mathrm{~V}$ represent, to some extent, a semi-circle due to the interchangeable interaction of the double-layer capacitance through the electrolyte-electrode interface and the charge-transfer resistance. However, at $+0.3 \mathrm{~V}$, the effect of charge-transfer resistance is such that with further decreasing frequency, the 
arc continues to rise vertically. This is a consequence of more than one factor. For instance, increasing the applied potential affects the charge-transfer resistance more significantly than the double-layer capacitance. Moreover, at $+0.3 \mathrm{~V}$ no further EOR occurs due to the $\mathrm{Pd}$ surface oxidation and current decrease (Figure 7). It is noteworthy the arc size at $-0.3 \mathrm{~V}$ and $0.0 \mathrm{~V}$ of $\mathrm{Pd}_{4} \mathrm{Ag}_{2} \mathrm{Ni}_{1} / \mathrm{C}$ is slightly smaller than their counterparts of $\mathrm{PdAgNi} / \mathrm{C}$.
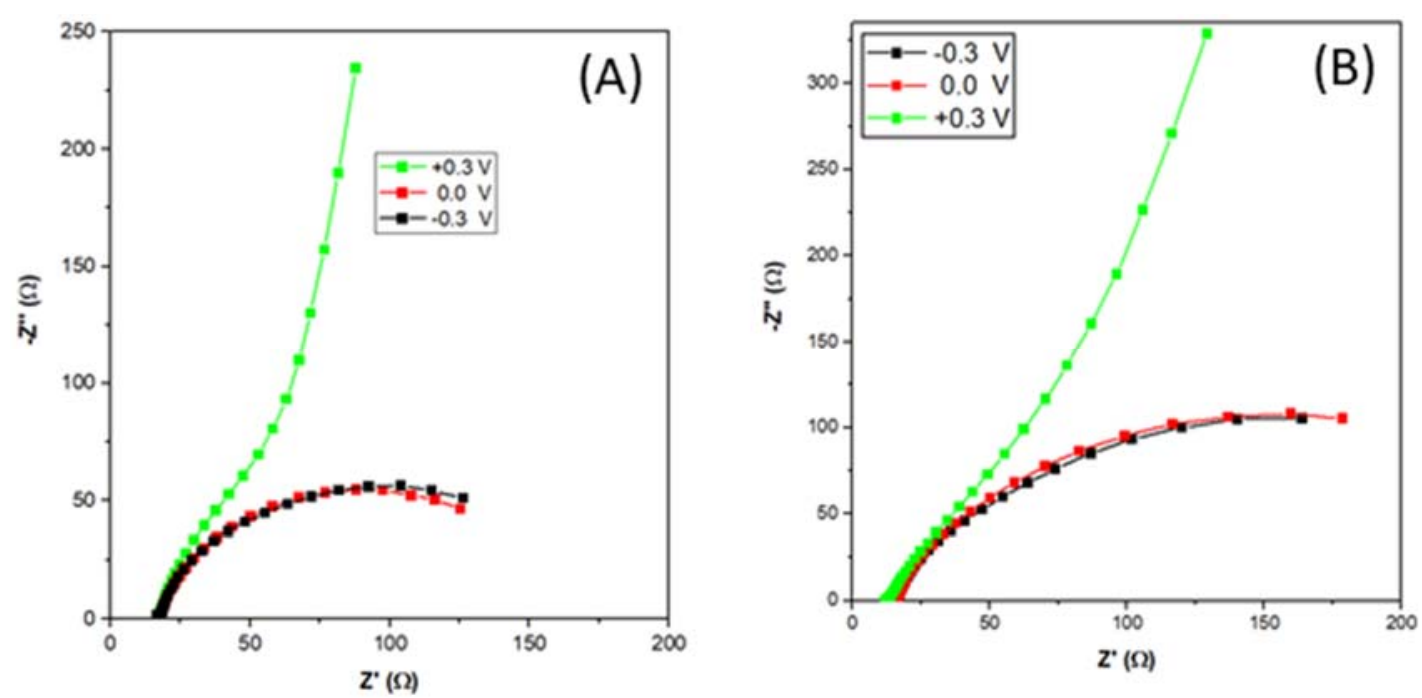

Figure 9. Electrochemical impedance spectroscopy (EIS) of $\mathrm{Pd}_{4} \mathrm{Ag}_{2} \mathrm{Ni}_{1} / \mathrm{C}(\mathbf{A})$ and $\mathrm{PdAgNi} / \mathrm{C}(\mathbf{B})$ at $-0.3 \mathrm{~V}, 0.0 \mathrm{~V}$, and $0.3 \mathrm{~V}$ vs. NHE.

Gamry Echem Analyst software was used to construct an electrical model (Figure 10) that represents the physical phenomena contributing to the impedance. $R_{s}$ represents the solution resistance measured at the intersection point with the $x$-axis $\left(-Z^{\prime \prime}=0\right.$, frequency $\left.=10 \mathrm{kHz}\right)$ and for both catalysts, it is approximately $14 \Omega$ and does not change with the applied potential. The constant-phase element $(\varnothing)$ represents the double-layer capacitance effect due to opposite-charge accumulation at the electrode-electrolyte interface. $R_{c t}$ represents the charge-transfer resistance that reflects on the specific activity of each catalyst. $R_{c t}$ values of $\mathrm{Pd}_{4} \mathrm{Ag}_{2} \mathrm{Ni}_{1} / \mathrm{C}$ are estimated to be $150 \Omega$ and $183 \Omega$ at $-0.3 \mathrm{~V}$ and $0.0 \mathrm{~V}$ vs. NHE, respectively. Larger values of $285 \Omega$ and $290 \Omega$ - at the same respective potentials-are obtained with $\mathrm{PdAgNi} / \mathrm{C}$. This further demonstrates the improved performance of $\mathrm{Pd}_{4} \mathrm{Ag}_{2} \mathrm{Ni}_{1} / \mathrm{C}$ towards EOR when compared to $\mathrm{PdAgNi} / \mathrm{C}$. It is difficult to estimate the $\mathrm{R}_{\mathrm{ct}}$ value at $+0.3 \mathrm{~V}$ due to the complex phenomena encountered and missing EOR at such high potential and several EIS models were inaccurate enough to estimate reasonable $R_{c t}$ values at that potential.

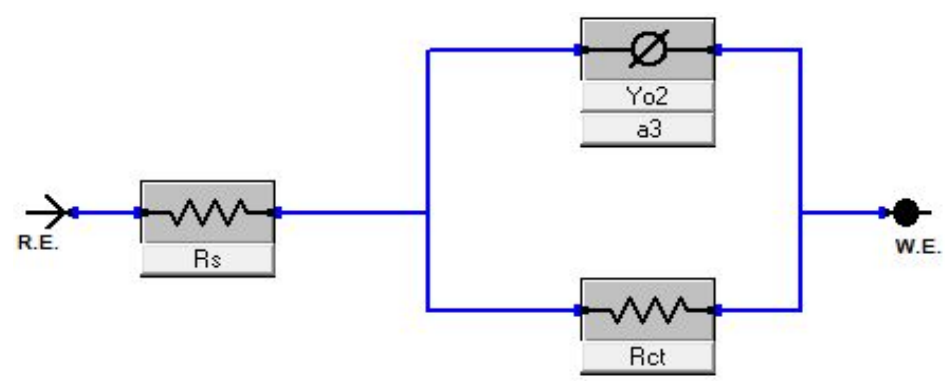

Figure 10. EIS electrical model representative of the physical quantities in a half-cell 3-electrode.

\section{Discussion}

The XRD peak separation of Pd and Ag (Figure 1) implies that there is substantial separation of $\mathrm{Pd}$ and $\mathrm{Ag}$ in the nanoparticles and therefore that it is less likely a nanoalloy has been formed. Separate Ag and Pd peaks were also reported by other researchers [31,60], while other groups have found singular peaks that resemble both $\mathrm{Pd}$ and $\mathrm{Ag}[30,39,61]$. 
Olivera et al. [32] annealed electrolessly deposited Pd and Ag films on steel discs to produce $\mathrm{Pd}-\mathrm{Ag}$ alloy films. Before annealing, distinctive $\mathrm{Pd}$ and $\mathrm{Ag}$ phases were detected by $\mathrm{XRD}$, with a single peak observed after annealing. The $\mathrm{Ni}(\mathrm{OH})_{2}$ individual peak disappearance in the XRD patterns of both trimetallic samples is suggestive of a high degree of mixing between $\mathrm{Pd}$ and $\mathrm{Ni}$ whose atoms could be assumed incorporated into the Pd lattice. The separate peaks of $\mathrm{Ni}(\mathrm{OH})_{2}$ are commonly seen when synthesizing bimetallic and trimetallic Ni-containing catalysts [22,29,53-55,62,63]. The surface metal loading of $\mathrm{PdAgNi} / \mathrm{C}$ (16 wt. \%), as measured by ESX, is 4 wt. \% higher than the nominal bulk loading (Table 1), with Ni segregating to the surface. The opposite trend is noted for Ag which segregates into the catalyst core. The Pd: Ag: Ni molar ratio at $10 \mathrm{kV}$ is 4:1:2 while it is 4:1.6:1 at $20 \mathrm{kV}$ which shows the Pd concentration does not change significantly with analysis depth, but the $\mathrm{Ag}$ and $\mathrm{Ni}$ ones do. A similar observation is noted for $\mathrm{PdAgNi} / \mathrm{C}$ whose Pd:Ag:Ni at $10 \mathrm{kV}$ is 2:1:4 while it is 1.75:1:2.25 at $20 \mathrm{kV}$.

According to the XPS measurements (Table 3), Ag is present exclusively in the metallic state with a concentration of 0.4 at. $\%$ and 0.32 at. $\%$ for $\mathrm{Pd}_{4} \mathrm{Ag}_{2} \mathrm{Ni}_{1} / \mathrm{C}$ and $\mathrm{PdAgNi} / \mathrm{C}$, respectively. This is despite the theoretical $\mathrm{Ag}$ loading being lower in $\mathrm{Pd}_{4} \mathrm{Ag}_{2} \mathrm{Ni}_{1} / \mathrm{C}$ (Table 1). It is noteworthy that XPS atomic Pd:Ag:Ni ratio is 4:1:2 while the ratio from surface-weighted EDX spectroscopy measurements (Table 2) is 4.4:1.7:1. The higher Ni XPS proportion signifies its segregation into the top surface unlike Ag. In $\mathrm{PdAgNi} / \mathrm{C}$, which has a lower fraction of $\mathrm{Pd}$ than $\mathrm{Pd}_{4} \mathrm{Ag}_{2} \mathrm{Ni}_{1} / \mathrm{C}$, the $\mathrm{Pd}$ air stability is lost and $15 \%$ of $\mathrm{Pd}$ exists in an oxidized form (Figure 5E) Figure 5G shows the Ni 2p peak of $\mathrm{PdAgNi} / \mathrm{C}$ and two satellite peaks which are potentially due to the multiple Ni excitations. No metallic $\mathrm{Ni}$ was detected for this sample and the Ni surface concentration equals 2.01 at.\%. Therefore, the XPS-derived Pd:Ag:Ni molar ratio is 2.7:1:6.7 while the EDX spectroscopy derived ratio (Table 2) is 1.7:2.3:1. Once again this is probably due to the Ni tendency to segregate into the surface and $\mathrm{Ag}$ and little Pd tendency to segregate into the core. In case of trimetallic samples, the $\mathrm{Pd} 3 \mathrm{~d}$ peak is shifted $0.05 \mathrm{eV}$ (Figure 5C) to higher binding energy than $\mathrm{Pd} / \mathrm{C}$, which may be suggestive of an electron loss from $\mathrm{Pd}$ to either $\mathrm{Ag}$ or Ni. Figure $5 \mathrm{C}$ shows the valence band of $\mathrm{Pd} / \mathrm{C}, \mathrm{Pd}_{4} \mathrm{Ag}_{2} \mathrm{Ni}_{1} / \mathrm{C}$, and $\mathrm{PdAgNi} / \mathrm{C}$ which indicates the $d$-band center of the two trimetallic samples are shifted approximately $1 \mathrm{eV}$ from the Fermi level compared to their monometallic counterpart. Note that the impact of particle size on $d$-band center can be neglected as the particle size is $\sim 5 \mathrm{~nm}$ and instead shifts in the $d$-band center are the consequence of charge transfer from Pd to other metals [35,64].

As $\mathrm{H}_{\mathrm{abs}}$ /des peak is missing in Figure 6, it is more appropriate to estimate electrochemical active surface area (ECSA) using the PdO reduction peak in the reverse scan. The $\mathrm{PdO}$ reduction area in the reverse scan is the smallest in case of $\mathrm{Pd} / \mathrm{C}$ while higher reduction currents are obtained with $\mathrm{PdAgNi} / \mathrm{C}$ and $\mathrm{Pd}_{4} \mathrm{Ag}_{2} \mathrm{Ni}_{1} / \mathrm{C}$. The $\mathrm{PdO}$ reduction peak is used as a measure of the $\mathrm{Pd}$ fraction exposed on the surface, and therefore, available to undertake redox reactions. The electrochemical active surface area $\left(\mathrm{ECSA}, \mathrm{cm}^{2} / \mathrm{mg}\right)$ is calculated according to [26]:

$$
E C S A=\frac{Q}{0.43 \times[P d]}
$$

where $Q$ is the charge extracted from $\mathrm{PdO}$ reduction peaks in $\mathrm{mC}, 0.43 \mathrm{mC} / \mathrm{cm}^{2}$ is the monolayer reduction charge of $\mathrm{Pd}$, and $[\mathrm{Pd}]$ is the weight of $\mathrm{Pd}$ on GCE in $\mathrm{mg}$. This indicates ECSA is highest on $\mathrm{Pd}_{4} \mathrm{Ag}_{2} \mathrm{Ni}_{1} / \mathrm{C}$ followed by $\mathrm{PdAgNi} / \mathrm{C}$ and finally $\mathrm{Pd} / \mathrm{C}$ (Table 4). This could be explained by the smaller particle size of both trimetallic samples compared to the monometallic one according to TEM (Figure 3). The three catalysts have very significantly larger ECSAs compared to the other materials listed in Table 4. This is indicative of the high Pd surface fraction; although Ni has a higher tendency to segregate into the surface as shown by EDX and XPS analyses. The low overall metal loading (12 wt. \%) decreases the overall metal surface energies and aggregation potential leading to a thicker and rougher catalyst layer, while the $\mathrm{KBr}$ capping works against agglomeration by surrounding the individual nanoparticles during synthesis with $\mathrm{Br}^{-1}$ ions. The ethanol-enhanced CV performance on both trimetallic samples is a reflection of 
the Ag and Ni effects. This indicates that more EOR Pd active sites exist on the trimetallic sample surfaces than on $\mathrm{Pd} / \mathrm{C}$. A similar finding was previously reported regarding the activity of PdAgNi towards formic acid oxidation [39]. The lower oxidation onset potentials and higher forward current peak are advantageous for the three samples in this work compared to many other previously published catalysts [58,65-67]. Table 4 compares the EOR onset oxidation current density and current peak obtained with this work catalysts and previously published ones. The reverse current peak of $\mathrm{Pd} / \mathrm{C}, \mathrm{Pd}_{4} \mathrm{Ag}_{2} \mathrm{Ni}_{1} / \mathrm{C}$, and $\mathrm{PdAgNi} / \mathrm{C}$ are smaller than their forward counterparts. This is indicative of a good $\mathrm{Pd}$ tolerance towards the poisoning species. When $\mathrm{o}_{\mathrm{f}} / \mathrm{j}_{\mathrm{b}}$ is $>1$, it implies less incompletely oxidized ethoxy intermediates on Pd surface which suggests the catalyst is more likely to recover its surface-active sites and proceed with further EOR. When it is $<1$, it suggests there are more incompletely-oxidized carbonaceous species on the catalyst surface that are strongly bound to active sites. Adding Ni to the Pd-based catalyst has, in some previous works, resulted in $\mathrm{j}_{\mathrm{f}} / \mathrm{j}_{\mathrm{b}}$ decreasing below $1[29,43]$, although other works observe the opposite trend $[42,54,68]$.

Table 4. Comparison of the ECSA $\left(\mathrm{cm}^{2} / \mathrm{mg}\right), \mathrm{E}_{\text {onset }}(\mathrm{mV})$ and $j_{\mathrm{p}}\left(\mathrm{A} / \mathrm{mg}_{\mathrm{Pd}}\right)$ in $1 \mathrm{M} \mathrm{EtOH}$ of this work and previously published catalysts.

\begin{tabular}{|c|c|c|c|c|}
\hline Catalyst & ECSA $\left(\mathrm{cm}^{2} / \mathrm{mg}\right)$ & $E_{\text {onset }}(\mathrm{mV})$ vs. NHE & $j_{\mathrm{p}}\left(\mathrm{A} / \mathrm{mg}_{\mathrm{Pd}}\right)$ & Ref. \\
\hline $\mathrm{Pd} / \mathrm{C}$ & 1350 & -390 & 1.8 & \multirow{3}{*}{ This work } \\
\hline $\mathrm{PdAgNi} / \mathrm{C}$ & 1500 & -500 & 2.7 & \\
\hline $\mathrm{Pd}_{4} \mathrm{Ag}_{2} \mathrm{Ni}_{1} / \mathrm{C}$ & 1618 & -500 & 2.3 & \\
\hline $\mathrm{Pd} / \mathrm{C}$ & 549 & -150 & 0.5 & \multirow{2}{*}{ [54] } \\
\hline $\mathrm{Pd}_{83} \mathrm{Ni}_{17}$ & 375 & -250 & 1.1 & \\
\hline $\mathrm{PdNi}$ & 209 & -260 & 1.45 & \multirow{2}{*}{ [29] } \\
\hline $\mathrm{Pd}$ & 135 & -209 & 0.8 & \\
\hline $\mathrm{Pd}_{1} \mathrm{Au}_{1} / \mathrm{C}$ & 1320 & -260 & 12 & \multirow{2}{*}{ [68] } \\
\hline $\mathrm{Pd} / \mathrm{C}$ & & -260 & 0.75 & \\
\hline $\mathrm{Pd}_{2} \mathrm{Sn}_{2} \mathrm{Ag}_{1} / \mathrm{C}$ & 243 & -360 & 0.8 & \multirow{3}{*}{ [42] } \\
\hline $\mathrm{Pd}_{2} \mathrm{Sn}_{2} \mathrm{Ni}_{1} / \mathrm{C}$ & 209 & -330 & 0.4 & \\
\hline $\mathrm{Pd}_{2} \mathrm{Sn}_{2} \mathrm{Co}_{1} / \mathrm{C}$ & 212 & -300 & 0.35 & \\
\hline $\mathrm{PdAgCu}$ & 506 & -360 & 4.56 & [43] \\
\hline $\mathrm{Pd} / \mathrm{C}$ & & -350 & 1.47 & \multirow{2}{*}{ [21] } \\
\hline $\mathrm{Pt} / \mathrm{C}$ & & -400 & 0.65 & \\
\hline
\end{tabular}

It should be noted the chronoamperometric currents drawn on trimetallic catalysts (Figure 8) are substantially higher than that on $\mathrm{Pd} / \mathrm{C}$ which suggests a higher catalyst capability to recover the $\mathrm{Pd}$ active sites by generating $\mathrm{OH}$ species which indicates the addition of $\mathrm{Ag}$ and $\mathrm{Ni}$ is beneficial for EOR catalytic performance. The catalyst containing the least $\mathrm{Pd}(\mathrm{PdAgNi} / \mathrm{C})$ draws the highest current density $(-0.3 \mathrm{~V})$. This implies that this surface is highly active for the generation of oxygen species, facilitating the removal of adsorbed ethoxy species. Ni surface segregation and Ag core segregation, as determined through EDX spectroscopy and XPS, may in part explain the enhanced $\mathrm{V}-j$ behavior of $\mathrm{PdAgNi} / \mathrm{C}$. A somewhat similar behavior is noted for the other trimetallic sample. Note, however, that a very high level of $\mathrm{OH}$ adsorption on the catalyst surface would negatively impact the overall catalyst performance as many of the EOR-active surface sites would be occupied by $\mathrm{OH}$.

The enhanced the performance of the trimetallic catalysts in the present work is likely due to $\mathrm{Ni}$ and $\mathrm{Ag}$ generating $\mathrm{OH}$ species resulting in the larger ECSA for both samples as shown in Figure 6 . The current density drawn on three catalysts at $+0.1 \mathrm{~V}$ is higher than at 
$-0.3 \mathrm{~V}$ due to the increased activation voltage and $\mathrm{OH}$ adsorption. It is also noteworthy that at $-0.3 \mathrm{~V}$ vs. NHE, the three catalysts exhibit similar behavior in terms of the current decays as the scan proceeds. However, at $-0.1 \mathrm{~V}$ vs. $\mathrm{NHE}, \mathrm{Pd}_{4} \mathrm{Ag}_{2} \mathrm{Ni}_{1} / \mathrm{C}$ shows better stability (stable current decay) than $\mathrm{PdAgNi} / \mathrm{C}$ even though the former draws a higher current for the majority of the 30 -min scan. Although the initial current decay at $-0.3 \mathrm{~V}$ is similar on both $\mathrm{Pd}_{4} \mathrm{Ag}_{2} \mathrm{Ni}_{1} / \mathrm{C}$ and $\mathrm{PdAgNi} / \mathrm{C}$, at $+0.1 \mathrm{~V}$ the current decay rate is higher for $\mathrm{PdAgNi} / \mathrm{C}$ than for $\mathrm{Pd}_{4} \mathrm{Ag}_{2} \mathrm{Ni}_{1} / \mathrm{C}$ and the former draws a higher current at the scan end. Several factors likely contribute to this enhanced performance upon adding both Ag and Ni. For instance, the activation barrier of EOR on both trimetallic samples less than that on $\mathrm{Pd} / \mathrm{C}$ due to the reduction of the bandgap energy, indicated by the smaller activation overvoltage [8]. Also, the large number of active sites verified by the smaller TEM particle size in the case of both trimetallic samples, will play a positive role. Another factor that may contribute to the observed higher ESCA values as compared to previous studies is that the experiment was performed with the electrolyte being stirred. This may help to ensure the uniform distribution of reactants/products and reduce the effects of mass transport and diffusion.

Compared to many reported synthesis methods, the currently applied method is quicker and easier because it is a room-temperature one-pot synthesis. Furthermore, it was concluded in a short time $(30 \mathrm{~min})$. Many of the previous synthesis protocols include use of high temperature and/or longer synthesis times [29,42,43,54,68]. Also, the smaller metal loading in the present work is potentially beneficial for the physical and electrochemical characteristics of the supported catalyst. Additionally, it is noted that $\mathrm{Ni}$ tends to segregate into the surface while Ag tends to segregate into the bulk of trimetallic particles. Furthermore, the trimetallic catalysts are cost-effective than those consisting only of platinum-group metals. The collective characterization and evaluation results suggest that $\mathrm{Pd}_{4} \mathrm{Ag}_{2} \mathrm{Ni}_{1} / \mathrm{C}$ is the best performing catalyst and that adding a significant Ni quantity (>35 At. \%) would adversely impact the catalyst physical and electrocatalytic performance

\section{Conclusions}

C-supported PdAgNi intermetallic catalysts have been successfully prepared through a straight-forward chemical synthesis method suitable for up-scaling for the first time. Adding small quantity of $\mathrm{Ni}$ in trimetallic catalysts has a beneficial impact but increasing the Ni content can harm the EOR performance. A relatively low metal loading (12 Wt. \%) and adding $\mathrm{KBr}$ as a capping agent are recommended to produce a well-dispersed catalyst with a high electrochemical surface area (ECSA). However, the followed protocol does not produce a highly order alloy structure of $\mathrm{Pd}$ and $\mathrm{Ag}$ as indicated by XRD. Although the $\mathrm{Pd}_{4} \mathrm{Ag}_{2} \mathrm{Ni}_{1} / \mathrm{C}$ surpassed the $\mathrm{PdAgNi} / \mathrm{C}$ in terms of ECSA and ethanol oxidation potential, the latter outperformed it in terms of the oxidation current peak and steady chronoamperometric current. Adding $\mathrm{Ag}$ and $\mathrm{Ni}$ to Pd not only improves its catalytic performance towards EOR, but considerably decreases the catalyst preparation cost. While $\mathrm{Ag}$ tends to segregate to the bulk of the PdAgNi nanoparticle, Ni tends to segregate to its outer surface layers. $\mathrm{Pd}_{4} \mathrm{Ag}_{2} \mathrm{Ni}_{1} / \mathrm{C}$ combines both high activity and stability towards EOR.

Author Contributions: Conceptualization, A.E. and J.M.; methodology, A.E.; software, A.E.; validation, J.M. and A.E.; investigation, A.E.; resources, J.M.; data curation, A.E.; writing-original draft preparation, A.E.; writing-review and editing, J.M. All authors have read and agreed to the published version of the manuscript.

Funding: Ahmed Elsheikh is grateful for the financial support of Newton-Mosharafa Fund (Reference No. NMJ8/15) of his Ph.D.

Data Availability Statement: Not applicable.

Acknowledgments: XPS data collection was performed at the EPSRC National Facility for XPS ('HarwellXPS'), operated by Cardiff University and UCL, under contract No. PR16195.

Conflicts of Interest: The authors declare there is no conflict of interest related to this work. 


\section{References}

1. Katsounaros, I.; Koper, M.T.M. Electrocatalysis for the hydrogen economy, In Electrochemical Science for a Sustainable Society; A Tribut. to John O'M Bockris; Springer International Publishing: Basel, Switzerland, 2017; pp. 23-50. [CrossRef]

2. Stamenkovic, V.R.; Strmcnik, D.; Lopes, P.; Markovic, N.M. Energy and fuels from electrochemical interfaces. Nat. Mater. 2017, 16, 57-69. [CrossRef]

3. O'Hayre, R.; Cha, S.-W.; Colella, W.; Prinz, F.B. Prinz, Fuel Cell Fundamentals; John Wiley \& Sons, Inc.: Hoboken, NJ, USA, 2016. [CrossRef]

4. Friedl, J.; Stimming, U. Model catalyst studies on hydrogen and ethanol oxidation for fuel cells. Electrochim. Acta 2013, 101, 41-58. [CrossRef]

5. Badwal, S.; Giddey, S.; Kulkarni, A.; Goel, J.; Basu, S. Direct ethanol fuel cells for transport and stationary applications-A comprehensive review. Appl. Energy 2015, 145, 80-103. [CrossRef]

6. Bianchini, C.; Shen, P.K. Palladium-Based Electrocatalysts for Alcohol Oxidation in Half Cells and in Direct Alcohol Fuel Cells. Chem. Rev. 2009, 109, 4183-4206. [CrossRef] [PubMed]

7. An, L.; Zhao, T.; Li, Y. Carbon-neutral sustainable energy technology: Direct ethanol fuel cells. Renew. Sustain. Energy Rev. 2015, 50, 1462-1468. [CrossRef]

8. O'Hayre, R.; Cha, S.; Colella, W.; Prinz, F.B. Chapter 3: Fuel Cell Reaction Kinetics. In Fuel Cell Fundam; John Wiley \& Sons, Inc.: Hoboken, NJ, USA, 2016; pp. 77-116. [CrossRef]

9. O'Hayre, F.B.P.R.; Cha, S.; Colella, W.; O’Hayre, R.; Cha, S.-W.; Colella, W.; Prinz, F.B. Chapter 8: Overview of Fuel Cell Types. In Fuel Cell Fundam; John Wiley \& Sons, Inc.: Hoboken, NJ, USA, 2016; pp. 269-302. [CrossRef]

10. Guo, J.; Chen, R.; Zhu, F.-C.; Sun, S.-G.; Villullas, H.D.L.M. New understandings of ethanol oxidation reaction mechanism on $\mathrm{Pd} / \mathrm{C}$ and Pd2Ru/C catalysts in alkaline direct ethanol fuel cells. Appl. Catal. B Environ. 2018, 224, 602-611. [CrossRef]

11. Kamarudin, M.; Kamarudin, S.; Masdar, M.S.; Daud, W.R.W. Review: Direct ethanol fuel cells. Int. J. Hydrog. Energy 2013, 38, 9438-9453. [CrossRef]

12. Antolini, E. Palladium in fuel cell catalysis. Energy Environ. Sci. 2009, 2, 915-931. [CrossRef]

13. Antolini, E.; Gonzalez, E. Alkaline direct alcohol fuel cells. J. Power Sources 2010, 195, 3431-3450. [CrossRef]

14. Merle, G.; Wessling, M.; Nijmeijer, K. Anion exchange membranes for alkaline fuel cells: A review. J. Membr. Sci. 2011, 377, 1-35. [CrossRef]

15. Brouzgou, A.; Podias, A.; Tsiakaras, P. PEMFCs and AEMFCs directly fed with ethanol: A current status comparative review. J. Appl. Electrochem. 2013, 43, 119-136. [CrossRef]

16. Sverdrup, H.U.; Ragnarsdottir, K.V. A system dynamics model for platinum group metal supply, market price, depletion of extractable amounts, ore grade, recycling and stocks-in-use. Resour. Conserv. Recycl. 2016, 114, 130-152. [CrossRef]

17. Khan, K.; Köseoğlu, S.D. Is palladium price in bubble? Resour. Policy 2020, 68, 101780. [CrossRef]

18. Hagelüken, C. Markets for the catalyst metals platinum, palladium and rhodium. Metall 2006, 60, 31-42.

19. Company news. Solder. Surf. Mt. Technol. 2012, 24, 433-434. [CrossRef]

20. Platinum, V.S. Palladium: A Key Factor Holding Back Platinum Demand and Price I Seeking Alpha. Available online: https:/ / seekingalpha.com/article/4270121-platinum-vs-palladium-key-factor-holding-back-platinum-demand-and-price (accessed on 24 January 2021).

21. Ma, L.; Chu, D.; Chen, R. Comparison of ethanol electro-oxidation on Pt/C and Pd/C catalysts in alkaline media. Int. J. Hydrog. Energy 2012, 37, 11185-11194. [CrossRef]

22. Amin, R.; Hameed, R.A.; El-Khatib, K.; Youssef, M.E. Electrocatalytic activity of nanostructured Ni and Pd-Ni on Vulcan XC-72R carbon black for methanol oxidation in alkaline medium. Int. J. Hydrog. Energy 2014, 39, 2026-2041. [CrossRef]

23. Sheikh, A.M.; Silva, E.L.; Moares, L.; Antonini, L.M.; Abellah, M.Y.; Malfatti, C.F. Pd-based Catalysts for Ethanol Oxidation in Alkaline Electrolyte. Am. J. Min. Metall. 2014, 2, 64-69. [CrossRef]

24. Obradović, M.; Stančić, Z.; Lacnjevac, U.; Radmilovic, V.; Gavrilovic-Wohlmuther, A.; Gojković, S. Electrochemical oxidation of ethanol on palladium-nickel nanocatalyst in alkaline media. Appl. Catal. B Environ. 2016, 189, 110-118. [CrossRef]

25. Jongsomjit, S.; Sombatmankhong, K.; Prapainainar, P. Effect of acid functionalised carbon supports for Pd-Ni-Sn catalyst on ethanol oxidation reaction. RSC Adv. 2015, 5, 61298-61308. [CrossRef]

26. Moraes, L.; Matos, B.; Radtke, C.; Santiago, E.; Fonseca, F.C.; Amico, S.; Malfatti, C. Synthesis and performance of palladium-based electrocatalysts in alkaline direct ethanol fuel cell. Int. J. Hydrog. Energy 2016, 41, 6457-6468. [CrossRef]

27. Zhang, Z.; Xin, L.; Sun, K.; Li, W. Pd-Ni electrocatalysts for efficient ethanol oxidation reaction in alkaline electrolyte. Int. J. Hydrog. Energy 2011, 36, 12686-12697. [CrossRef]

28. Hassaninejad-Darzi, S.K.; Gholami-Esfidvajani, M. Electrocatalytic oxidation of ethanol using modified nickel phosphate nanoparticles and multi-walled carbon nanotubes paste electrode in alkaline media for fuel cell. Int. J. Hydrog. Energy 2016, 41, 20085-20099. [CrossRef]

29. Feng, Y.; Bin, D.; Yan, B.; Du, Y.; Majima, T.; Zhou, W. Porous bimetallic PdNi catalyst with high electrocatalytic activity for ethanol electrooxidation. J. Colloid Interface Sci. 2017, 493, 190-197. [CrossRef] [PubMed]

30. Jo, Y.-G.; Kim, S.-M.; Kim, J.-W.; Lee, S.-Y. Composition-tuned porous Pd-Ag bimetallic dendrites for the enhancement of ethanol oxidation reactions. J. Alloy. Compd. 2016, 688, 447-453. [CrossRef] 
31. Li, L.; Chen, M.; Huang, G.; Yang, N.; Zhang, L.; Wang, H.; Liu, Y.; Wang, W.; Gao, J. A green method to prepare Pd-Ag nanoparticles supported on reduced graphene oxide and their electrochemical catalysis of methanol and ethanol oxidation. J. Power Sources 2014, 263, 13-21. [CrossRef]

32. Oliveira, M.; Rego, R.; Fernandes, L.S.G.; Tavares, P. Evaluation of the catalytic activity of Pd-Ag alloys on ethanol oxidation and oxygen reduction reactions in alkaline medium. J. Power Sources 2011, 196, 6092-6098. [CrossRef]

33. Qi, J.; Benipal, N.; Liang, C.; Li, W. PdAg/CNT catalyzed alcohol oxidation reaction for high-performance anion exchange membrane direct alcohol fuel cell (alcohol = methanol, ethanol, ethylene glycol and glycerol). Appl. Catal. B Environ. 2016, 199, 494-503. [CrossRef]

34. Lam, B.T.X.; Chiku, M.; Higuchi, E.; Inoue, H. Preparation of PdAg and PdAu nanoparticle-loaded carbon black catalysts and their electrocatalytic activity for the glycerol oxidation reaction in alkaline medium. J. Power Sources 2015, 297, 149-157. [CrossRef]

35. Hu, S.; Munoz, F.; Noborikawa, J.; Haan, J.; Scudiero, L.; Ha, S. Carbon supported Pd-based bimetallic and trimetallic catalyst for formic acid electrochemical oxidation. Appl. Catal. B Environ. 2016, 180, 758-765. [CrossRef]

36. Beyhan, S.; Léger, J.-M.; Kadırgan, F. Understanding the influence of Ni, Co, Rh and Pd addition to PtSn/C catalyst for the oxidation of ethanol by in situ Fourier transform infrared spectroscopy. Appl. Catal. B Environ. 2014, 144, 66-74. [CrossRef]

37. Shang, C.; Hong, W.; Wang, J.; Wang, E. Carbon supported trimetallic nickel-palladium-gold hollow nanoparticles with superior catalytic activity for methanol electrooxidation electrooxidation. J. Power Sources. 2015, 85, 12-15. [CrossRef]

38. Sharma, G.; Kumar, D.; Kumar, A.; Al-Muhtaseb, A.; Pathania, D.; Naushad, M.; Mola, G.T. Revolution from monometallic to trimetallic nanoparticle composites, various synthesis methods and their applications: A review. Mater. Sci. Eng. C 2017, 71, 1216-1230. [CrossRef]

39. Ulas, B.; Caglar, A.; Sahin, O.; Kivrak, H. Composition dependent activity of PdAgNi alloy catalysts for formic acid electrooxidation. J. Colloid Interface Sci. 2018, 532, 47-57. [CrossRef] [PubMed]

40. Shen, S.; Zhao, T.; Xu, J.; Li, Y. High performance of a carbon supported ternary PdIrNi catalyst for ethanol electro-oxidation in anion-exchange membrane direct ethanol fuel cells. Energy Environ. Sci. 2011, 4, 1428-1433. [CrossRef]

41. Su, P.-C.; Chen, H.-S.; Chen, T.-Y.; Liu, C.-W.; Lee, C.-H.; Lee, J.-F.; Chan, T.-S.; Wang, K.-W. Enhancement of electrochemical properties of $\mathrm{Pd} / \mathrm{C}$ catalysts toward ethanol oxidation reaction in alkaline solution through Ni and Au alloying. Int. J. Hydrog. Energy 2013, 38, 4474-4482. [CrossRef]

42. Zhu, F.; Wang, M.; He, Y.; Ma, G.; Zhang, Z.; Wang, X. A comparative study of elemental additives (Ni, Co and Ag) on electrocatalytic activity improvement of PdSn-based catalysts for ethanol and formic acid electro-oxidation. Electrochim. Acta 2014, 148, 291-301. [CrossRef]

43. Lv, H.; Sun, L.; Zou, L.; Xu, D.; Yao, H.; Liu, B. Electrode for proton exchange membrane fuel cells: A review. Chem. Sci. 2019, 10, 1986-1993. [CrossRef]

44. Gebre, S.H.; Sendeku, M.G. Trimetallic nanostructures and their applications in electrocatalytic energy conversions. J. Energy Chem. 2022, 65, 329-351. [CrossRef]

45. Zhu, W.; Ke, J.; Wang, S.-B.; Ren, J.; Wang, H.-H.; Zhou, Z.-Y.; Si, R.; Zhang, Y.-W.; Yan, C.-H. Shaping Single-Crystalline Trimetallic Pt-Pd-Rh Nanocrystals toward High-Efficiency C-C Splitting of Ethanol in Conversion to CO $_{2}$. ACS Catal. 2015, 5, 1995-2008. [CrossRef]

46. Nandenha, J.; De Souza, R.; Assumpção, M.; Spinacé, E.V.; Neto, A.O. Preparation of PdAu/C-Sb $2 \mathrm{O}_{5} \cdot \mathrm{SnO}_{2}$ electrocatalysts by borohydride reduction process for direct formic acid fuel cell. Ionics 2013, 19, 1207-1213. [CrossRef]

47. Neto, A.O.; Tusi, M.M.; Polanco, N.S.D.O.; da Silva, S.G.; dos Santos, M.C.; Spinacé, E.V. PdBi/C electrocatalysts for ethanol electro-oxidation in alkaline medium. Int. J. Hydrog. Energy 2011, 36, 10522-10526. [CrossRef]

48. Assumpção, M.; da Silva, S.; De Souza, R.; Buzzo, G.; Spinacé, E.; Santos, M.; Neto, A.; Silva, J. Investigation of PdIr/C electrocatalysts as anode on the performance of direct ammonia fuel cell. J. Power Sources 2014, 268, 129-136. [CrossRef]

49. Antoniassi, R.; Silva, J.C.; Neto, A.O.; Spinacé, E. Synthesis of Pt+SnO2/C electrocatalysts containing Pt nanoparticles with preferential (100) orientation for direct ethanol fuel cell. Appl. Catal. B Environ. 2017, 218, 91-100. [CrossRef]

50. Naresh, N.; Wasim, F.G.S.; Ladewig, B.P.; Neergat, M. Removal of surfactant and capping agent from Pd nanocubes (Pd-NCs) using tert-butylamine: Its effect on electrochemical characteristics. J. Mater. Chem. A 2013, 1, 8553-8559. [CrossRef]

51. Leng, Y. X-ray Spectroscopy for Elemental Analysis. In Materials Characterization; John Wiley \& Sons, Ltd.: Chichester, UK, 2008; pp. 171-196. [CrossRef]

52. Meng, Y. A Sustainable Approach to Fabricating Ag Nanoparticles/PVA Hybrid Nanofiber and Its Catalytic Activity. Nanomaterials 2015, 5, 1124-1135. [CrossRef]

53. Ramulifho, T.; Ozoemena, K.I.; Modibedi, R.M.; Jafta, C.; Mathe, M. Fast microwave-assisted solvothermal synthesis of metal nanoparticles (Pd, Ni, Sn) supported on sulfonated MWCNTs: Pd-based bimetallic catalysts for ethanol oxidation in alkaline medium. Electrochim. Acta 2012, 59, 310-320. [CrossRef]

54. Zhu, C.; Wen, D.; Oschatz, M.; Holzschuh, M.; Liu, W.; Herrmann, A.-K.; Simon, F.; Kaskel, S.; Eychmüller, A. Kinetically Controlled Synthesis of PdNi Bimetallic Porous Nanostructures with Enhanced Electrocatalytic Activity. Small 2015, 11, 1430-1434. [CrossRef]

55. Dutta, A.; Datta, J. Energy efficient role of $\mathrm{Ni} / \mathrm{NiO}$ in PdNi nano catalyst used in alkaline DEFC. J. Mater. Chem. A 2014, 2, 3237-3250. [CrossRef] 
56. Dutta, A.; Datta, J. Outstanding Catalyst Performance of PdAuNi Nanoparticles for the Anodic Reaction in an Alkaline Direct Ethanol (with Anion-Exchange Membrane) Fuel Cell. J. Phys. Chem. C 2012, 116, 25677-25688. [CrossRef]

57. Armenta-González, A.J.; Carrera-Cerritos, R.; Guerra-Balcázar, M.; Arriaga, L.G.; Ledesma-García, J. Comparative study of carbon-supported $\mathrm{Pd}$ and $\mathrm{PdAg}$ catalysts synthesised by the polyol process and reverse micelles methods. J. Appl. Electrochem. 2014, 45, 33-41. [CrossRef]

58. Chen, L.Y.; Chen, N.; Hou, Y.; Wang, Z.C.; Lv, S.H.; Fujita, T.; Jiang, J.H.; Hirata, A.; Chen, M.W. Geometrically Controlled Nanoporous PdAu Bimetallic Catalysts with Tunable Pd/Au Ratio for Direct Ethanol Fuel Cells. ACS Catal. 2013, 3, 1220-1230. [CrossRef]

59. Zalineeva, A.; Serov, A.; Padilla, M.; Martinez, U.; Artyushkova, K.; Baranton, S.; Coutanceau, C.; Atanassov, P. Nano-structured Pd-Sn catalysts for alcohol electro-oxidation in alkaline medium. Electrochem. Commun. 2015, 57, 48-51. [CrossRef]

60. Adekoya, J.; Dare, E.; Mesubi, M.; Nejo, A.A.; Swart, H.; Revaprasadu, N. Synthesis of polyol based Ag/Pd nanocomposites for applications in catalysis. Results Phys. 2014, 4, 12-19. [CrossRef]

61. Zhang, Y.; Yi, Q.; Deng, Z.; Zhou, X.; Nie, H. Excellent Electroactivity of Ternary Pd-Ag-Sn Nanocatalysts for Ethanol Oxidation. Catal. Lett. 2018, 148, 1190-1201. [CrossRef]

62. Wei, Y.-C.; Liu, C.-W.; Kang, W.-D.; Lai, C.-M.; Tsai, L.-D.; Wang, K.-W. Electro-catalytic activity enhancement of Pd-Ni electrocatalysts for the ethanol electro-oxidation in alkaline medium: The promotional effect of $\mathrm{CeO}_{2}$ addition. J. Electroanal. Chem. 2011, 660, 64-70. [CrossRef]

63. Wang, Y.; Jiang, K.; Cai, W.-B. Enhanced Electrocatalysis of Ethanol on Dealloyed Pd-Ni-P Film in Alkaline Media: An Infrared Spectroelectrochemical Investigation. Electrochim. Acta 2015, 162, 100-107. [CrossRef]

64. Pan, B.; Chen, F.; Kou, B.; Wang, J.; Tang, Q.; Guo, L.; Wang, Q.; Li, Z.; Bian, W.; Wang, J. Unexpectedly high stability and surface reconstruction of PdAuAg nanoparticles for formate oxidation electrocatalysis. Nanoscale 2020, 12, 11659-11671. [CrossRef] [PubMed]

65. Chen, X.-M.; Lin, Z.-J.; Jia, T.-T.; Cai, Z.-M.; Huang, X.-L.; Jiang, Y.-Q.; Chen, X.; Chen, G.-N. A facile synthesis of palladium nanoparticles supported on functional carbon nanotubes and its novel catalysis for ethanol electrooxidation. Anal. Chim. Acta 2009, 650, 54-58. [CrossRef]

66. Correa, P.D.S.; Da Silva, E.L.; Da Silva, R.F.; Radtke, C.; Moreno, B.; Chinarro, E.; Malfatti, C. Effect of decreasing platinum amount in Pt-Sn-Ni alloys supported on carbon as electrocatalysts for ethanol electrooxidation. Int. J. Hydrog. Energy 2012, 37, 9314-9323. [CrossRef]

67. Habibi, E.; Bidad, E.; Feizbakhsh, A.; Fazli, M. Comparative electrooxidation of C1-C4 alcohols on Pd I CC nanoparticle anode catalyst in alkaline medium. Int. J. Hydrog. Energy 2014, 39, 18416-18423. [CrossRef]

68. Feng, Y.-Y.; Liu, Z.-H.; Xu, Y.; Wang, P.; Wang, W.-H.; Kong, D.-S. Highly active PdAu alloy catalysts for ethanol electro-oxidation. J. Power Sources 2013, 232, 99-105. [CrossRef] 